Article

\title{
Is Romania Prepared for eLearning during the COVID-19 Pandemic?
}

\author{
Eduard Edelhauser ${ }^{1, *}$ and Lucian Lupu-Dima ${ }^{2}$ (I) \\ 1 Department of Management and Industrial Engineering, University of Petroșani, 332003 Petrosani, Romania \\ 2 Department of Mining Engineering, Surveying and Construction, University of Petroșani, 332003 Petroșani, \\ Romania; lucianlupu@upet.ro \\ * Correspondence: eduardedelhauser@upet.ro; Tel.: +40-7-2256-2167
}

Received: 12 June 2020; Accepted: 1 July 2020; Published: 6 July 2020

check for updates

\begin{abstract}
Today, Romanian universities largely have eLearning platforms generally based on the most popular Moodle-LMS platform or on the most popular collaborative educational platforms designed by Microsoft and Google, which contain mail group modules, virtual classes, video conferencing, presentation and testing. In the context of the pandemic generated by COVID-19, the authors tried to investigate the way in which Romanian society has managed to face this challenge in the field of education. The events followed one another very quickly, and the first thing that crashed was the medical system, quickly followed by the economic environment and then, obviously, education. The authors' research methodology was based on the interpretation of the results of a questionnaire composed of 19 questions and applied to a population of 200 respondents. The survey period was only 24 h, between 29 April 2020 at 1 p.m. and 30 April 2020 at 1 p.m. The investigated population, the respondents, were students of the University of Petroșani undertaking bachelor and master studies for the academic year 2019-2020, but the study could be extrapolated to the Romanian education system.
\end{abstract}

Keywords: eLearning; collaborative education platform; Learning Management System platform; education for sustainable development; virtual classroom; teaching process

\section{Introduction}

Even if virtual education has been a concern of the educational system and implicitly of the management of educational institutions in the past, in the context of the pandemic generated by the COVID-19 virus, virtual education has become a challenge not only for the education system but for the society as a whole. It is obvious that every participant in the education system needs to be continuously informed about the new trends in eLearning so that the education system can keep up with new students, born in a digital era. There have been worldwide concerns about distance learning since the 1900s; thus, distance education by radio appeared in 1920; in 1945, distance learning by television started; and after the internet became accessible, so after 1995, eLearning also appeared. In the period 2010-2020, the performance of virtual education has reached impressive levels. It is well-known that Virtual Education was another name used for eLearning but referring more to electronically aided learning conducted without any face-to-face components. Now, in the context of the COVID-19 pandemic, the whole education system has changed from a classical education system to an online education system based on eLearning. However, what became eLearning in the last ten years? eLearning is now much more than virtual education, and in the context of the COVID-19 pandemic, it became a social phenomenon.

According to Castle, one of the biggest assumptions commonly made in the development of eLearning programs is that the more visually appealing a program, the more the learning that will 
occur; therefore, it is easy to assume that the way to create a premier eLearning course is to simply add more media (such as animations, videos and illustrations). This is not necessarily true since the purpose of media elements should be to deliver the content and instructional methods, not to make a program merely look appealing. Visual appeal, therefore, is simply a byproduct of good instructional design. A truly premier eLearning course is one that will look attractive, feel vibrant, encourage participation, and incorporate activities that support the learning objectives and various learning styles of its participants. In addition, it will combine elements of synchronous and asynchronous learning in a way that maximizes student engagement while maintaining the core course objectives and goals.

Online course delivery can be an effective way of obtaining multiple goals in sustainable education. It offers the benefits of educational access for a wide array of potential students, while also limiting the carbon intensity of course delivery. However, the benefits suggested in the literature, including the notion of "deep learning" through reflective asynchronous delivery methods, are not clearly reflected in this study of student self-assessment of learning. Rather, students seem to desire a mixed balance of synchronous and asynchronous delivery methods when engaging in the online environment. This is an important factor to consider when thinking about the overall benefits of online education in meeting sustainability goals [1].

Nie showed that there is a relationship between the development of eLearning for sustainable development and upward trends in the economic efficiency of education. Thus, the effective digitalization of the education system requires higher Internet coverage and higher digital literacy of the population, while Russia has a heterogeneity across regions concerning the latter. Thus, the electronic segment of education meets the general principle of lifelong education, which reinforces the sustainability aspect. An eLearning financing model proposed for the Russian reality will allow all subjects of this process to develop in accordance with the requirements of the time and improve information technology. At the same time, comprehensive methodology for financing eLearning serves as a tool for improving the education system generally and incorporates the most important components of the sustainable development of society [2].

According to Kubiatko, that the correct use of ICT in the learning process is a very important part of education, because if students do not quickly obtain reliable types of information from a teacher, they are able to find the required information alone, and the information could be from an unverified source and can create a wrong understanding of the phenomenon [3].

The authors have tried in this study to evaluate "The impact induced by online courses or eLearning on students" in this special situation induced by the COVID-19 crisis. They have focused their investigation on the eLearning hardware and software tools that have been used by teachers and students for teaching and examination. Additionally, they tried to overview the level of participation in online courses and the impact induced by this type of education on students.

The authors started this investigation in the University of Petrosani, a small university that could be considered representative for the whole Romanian education system, based on the fact that primary, secondary and high schools and also small universities are similar in field of the online education, because, unfortunately, they only started the massive implementation and use of eLearning on 15 March 2020. Additionally, primary, secondary and high schools and small universities represent $88.80 \%$ of the pupils and students involved in the Romanian education system, because only 327,471 students follow the courses of the top universities-the 17 universities that have more than 10,000 students and had a developed online systems for distance education-out of the total of 2,926,168 pupils and students enrolled in the Romanian education system in the 2019-2020 academic year.

The Romanian National Council for the Financing of Higher Education statistics offer the total number of the Romanian students for the 2019/2020 academic year-459,899. The same statistics show that from the total of the 49 Romanian State Universities, 32 are small universities having around 5000 students and representing 30\% of Romanian students. On the other hand, these small universities are very important and are representative because most of them are comprehensive universities, having 
the most important fundamental areas of study such as engineering, social science and humanities. The University of Petrosani is such a small university, having 3565 students including PhD students and, as areas of study, engineering and social science [4].

In the field of eLearning, all these small universities are similar; they did not previously have distance learning, so they have to adjust very quickly to the new conditions of education generated by the COVID-19 Pandemic. Additionally, these small universities could not afford to buy an eLearning platform produced by one of the major world players in this field. These small universities have adopted low-priced eLearning platforms such as LMSs developed on Moodle or free collaborative educational platforms. During the 2016-2020 period, Eduard Edelhauser was the vice rector of the University of Petrosani in the field of management and has numerous contacts with his colleagues from the other small universities [5].

The Romanian National Institute of Statistics offer the total number of the Romanian pupils for the 2018/2019 scholastic year, for ISCED 1, 2 or 3 (International Standard Classification of Education) - 2,466,269 [6]. In the field of eLearning, all these primary, secondary and high schools had no experience, and they had to adapt very quickly to an elementary form of eLearning. Considering the huge number of pupils involved at this level of study, teachers adopt simple forms of online education such as email or WhatsApp file transfers, video conferencing and, a few of them, freeware designed virtual classes.

Based on these data and on the situation well known by the authors from the University of Petrosani, the authors started an investigation of the eLearning tools used at the University of Petrosani in the COVID-19 pandemic period, considered representative of the Romanian education system in the field of eLearning.

\section{Materials and Methods}

In this paper, the authors analyzed eLearning as a social phenomenon in the whole Romanian education system during the coronavirus pandemic period. The 2020 coronavirus crisis has shown an old weakness of the Romanian education system, the incomplete adaptation of the teaching process to the use of digital tools. In the Romanian education system, eLearning became a must on 15 March 2020, when the whole education system was reset for eLearning because of the state of emergency.

\subsection{Theoretical Background}

In Ellis and Goodyear's opinion, the use of ICT (Information and Communication Technologies) to increase educational flexibility raises fundamental questions about what is essential to a university. It raises questions about the value of having a physical campus. By allowing teaching to be casualized and outsourced, it raises questions about the links between research and teaching, and about who should be seen as core members of the academic body. Blurring the boundaries around distance-learning-what is distance?-makes some universities footloose; less attached to place, they face huge questions about identity, brand, market, loyalty and competitive edge [7].

The COVID-19 pandemic represents a crisis for the whole world, but maybe a challenge for the education system. A challenge and also a test for the relationship between face-to-face education and virtual education, a trigger for the transition to a new education system. From now on, virtual education or eLearning must be analyzed as an education phenomenon from an ICT perspective.

In the foreword of the Ellis and Goodyear research report, Diana Laurillard from the London Knowledge Lab, Institute of Education alleges that in the last 40 years or so, universities have had to contend with many changes-political, social, cultural, economic and technological-but the most dramatic of these is technological. She also highlights that the response of university communities has been to embrace all these technological challenges, in the sense that these and others can all be found in active use on every campus now. However, that is not quite the same as harnessing the technology to the educational ends and the fundamental values of academic life. We risk being led inexorably by technology in its own ever-changing directions as we pursue each new and intriguing invention. 
Another important reflection of Laurillard is that the affordances of a new technology are not sufficient to judge its value. For example, online forums afford flexible student interaction, but the history of their research and evaluation is full of disappointment. They play a particular role within the rich mix of formal and informal learning experiences of a student, but without an appreciation of that, they fail [7].

In this paper, the authors consider that is important to also analyze eLearning from a social perspective. To demonstrate what eLearning represents for an education system, they first analyzed the engagement in eLearning environments in other education systems. Lee, Song and Hong conducted research in a Korean university in 2018, and they demonstrated that student engagement in eLearning is composed of six factors: psychological motivation, peer collaboration, cognitive problem solving, interactions with instructors, community support, and learning management [8]. Other research reports on students' experiences with eLearning conducted by authors in the United States, Europe and Australia help higher education instructors/teachers and university managers understand how eLearning relates to, and can be integrated with, other student experiences of learning. However, in their reviewing of the previous literature on student engagement, they also found that the following behaviors are important indicators of student engagement in face-to-face learning environments: learning effort, participation in class activities, interaction, cognitive task solving, learning satisfaction, a sense of belonging and learning passion. The findings of Lee, Song and Hong's study correlated with those of previous studies demonstrating that the main factors of student engagement are behavioral, cognitive and emotional engagement.

Even online learning is also a very challenging environment for developing the self-regulated capacities of learners; learners who do not self-regulate in learning will face difficulties in engaging in learning [9]. There are a lot of deficiencies of eLearning, such as the distance between instructors and learners, that make rich communication difficult and make them participate persistently and efficiently in online learning, so they cannot continuously engage in online learning [10]. Additionally, despite the advantages, one important problem in eLearning is the higher dropout rate [11].

In 2020, education cannot be detached from ICT, and Kubiatko made some pertinent reflections on this connection. He alleges that the present time is bringing new challenges for teachers and also for pupils [3]. One important thing is to realize that the use of ICT not only occurs in classes but also in out-of-school activities. The teachers were alerted to the use of ICT only in schools, but in many cases, the teachers did not notice the massive and huge advent of the use of social sites, nor the use of smartphones and other mobile devices, which can influence the communication and also teaching process [12,13]. Via the Internet, children are now able to surf and search for information, play games, watch videos and even make use of numerous online services such as making and receiving VoIP calls using Skype. Additionally, mobile learning (m-learning) influences the life of teachers and pupils. M-learning is a rapidly developing paradigm driven by exponential changes in the capabilities of mobile technologies and their integration with Web 2.0 (the second generation of World Wide Web) social software. The worldwide market share of mobile devices is increasing, eclipsing traditional computer ownership [14]. M-learning (mobile learning) technologies provide the ability to engage in learning conversations between students and lecturers, student peers, students and subject experts, and students and authentic environments within any context. It provides the potential for mobile learning to bridge pedagogically designed learning contexts and facilitate learner-generated contexts and content (both personal and collaborative), while providing personalization and ubiquitous social connectedness that sets it apart from more traditional learning environments [14].

Another important analysis of eLearning from an ICT perspective was performed by Orozco, Martínez and Gonzálvez-Pons, in a recent study performed by specialists from the Polytechnic University of Valencia. They studied a pilot academic implementation of the resources developed through a project called PETRA into a virtual collaborative master's-level research project, constructed incorporating individual work as complementary elements of the project [15]. They studied 
the development of a Technology Enhanced Learning (TEL) strategy in selected Azerbaijani universities [16] in a cooperative manner with five EU universities. In Azerbaijan, a new 2009 education law nominally introduced the European Credit Transfer System in the country; in Romania in 2005 began the Bologna process, and a new education law was established in 2011, so there are a lot of similarities between the two countries. They have demonstrated the efficiency of TEL for curriculum development in Azerbaijan. They showed that team capacity development has been key to the success of the new courses, that the first official academic application will be addressing an EU cooperative project focused on teacher training for widening the future implementation of the methodology, and that efficiency led to excellent implementation, which involved motivation and a good combination of leadership regarding supervision. These elements were facilitated by the pilot design and the focus on interdisciplinary project work. Similar results have been demonstrated as key for initial deployment as in the case of South Carolina [17].

In Romania, one of the most important IT companies, SIVECO, has implemented the AeL Enterprise Platform. AeL Enterprise is a complex platform for the teaching, learning, evaluation and management of multimedia educational content, providing any organization with a complete, flexible and secure training solution. For optimal training, the system allows the use of the AeL digital content repository, a unique collection of multimedia learning objects that can be developed for any teaching subject, from any activity area, depending on an organization's needs. In 2010, when the authors performed two major studies $[18,19]$ of AeL platform implementation in Romania with SIVECO specialists, they concluded that over 15,000 schools from Europe, the Middle East, Africa and CIS (Commonwealth og Independent States - former Soviet Union) had already experienced the AeL eLearning solution. The extensive AeL eContent Library includes over 3700 interactive lessons on 21 subjects, and over 16,000 reusable learning objects.

At the end of this short theoretical background that is related to eLearning's social implications, the authors have identified a recent study, similar to the authors' study during the COVID-19 pandemic, that was published in May 2020 by a group of researchers from Mexico [20]. They demonstrated that higher education institutions could largely benefit from the implementation of Learning Management Systems (LMSs). From a social standpoint, universities would be able to better train individuals, develop knowledge and share updated information that could be accessed at any time. Carrying out the activities through virtual courses eliminates the use of paper completely, and this, in turn, reduces deforestation, considering that large technology companies-such as Facebook, Google, and Microsoft, among others-are making modifications to achieve the sustainability of their servers through renewable energy sources, namely wind, solar, and blue energy, along with a reduction in environmental pollution in terms of transportation, electricity, construction and maintenance. In their opinion, LMSs offer a great affordable alternative to face-to-face classes through free virtual classes when school activities have to cease in the case of a state of emergency, such as the one prompted by the COVID-19 pandemic. The results showed good reception of such methods, with $31 \%$ of the students preferring LMSs over traditional classes. A pandemic such as COVID-19 involves taking measures of physical distancing between teachers and students, which does not necessarily imply that school activities have to stop. As shown in their research, all six of the courses proposed were able to be conducted virtually. Virtual education using Tools Leaning (TLs)—such as Zoom groups, Facebook, etc.-is evidently all the more efficient when we take a look at the results, where $89 \%$ of the most efficient students used these tools, and within this group, $85 \%$ used Mobile Use (MU) and $82 \%$ used Virtual Libraries (VLs). 


\subsection{An Overview of the Educational Platforms}

2.2.1. An Overview of the Online Educational Platforms around the World, in the Context of the COVID-19 Pandemic

Today's education without the Internet is inconceivable, because of the technological transformation to which humanity has been subjected. Ignoring the trend of digitalization is the equivalent of refusing to progress.

Górska states that eLearning brings a new quality to academic education. The openness of the universities to the introduction of a variety of learning and teaching methods using an interactive method of communication is a response to the expectations of the young generation of today. Access to advanced technologies is very highly valued by young people accustomed to the daily use of electronic media. Many high school students approaching future studies at university are guided by the possibility of following courses offered not only with traditional methods [21].

Using eLearning only for this is currently a wrong approach. It is important that the beneficiaries of the educational process benefit from a good quality education that results in consolidating their training. Vagarinho conducted a study with respondents from around the world, and according to him, $87.5 \%$ appreciate that they Agree and Strongly Agree with the statement "Quality is useful for e-learning" [22].

According to a study published by Bestcolleges, a Red Ventures Company, under the coordination of Melissa A. Veneable-an online education advisor for BestColleges-regarding Tracking trends in learner demographics and program development with insights from students and administrators, $77 \%$ of online students enroll in their programs to help them reach career and employment goals, $47 \%$ of school administrators report trends in student demographics related to age, $25 \%$ see students trending older, and $20 \%$ see them trending younger. School administrators also see some increased diversity related to gender and ethnic groups in their student enrolment online. Additionally, "Reputation of a specific school" ranked low again this year in the reasons students choose online learning over on-campus learning.

The feedback received from students is very important. Student satisfaction with online learning is high-overall, 94\% say it has, or will have, a positive Return of Investment (ROI), and 95\% would recommend online education to others. Additionally, $49 \%$ of American school administrator respondents said prospective students are asking about the placement or employment rates of online program graduates [23].

Proof of the reality of the use of digital technology in education is found in the 2019 EU Education and Training Monitor, which shows on the Intensity of use of digital technologies in lessons by teachers the fact that Teachers design the learning activities of their students and are thus instrumental for implementing digital teaching and learning practices. A majority of the students in the EU currently have teachers using digital technologies in at least a quarter of their classes $(71 \%$ at the primary level, $58 \%$ at the lower secondary level, and $65 \%$ at the upper secondary level). The intensity of the use of digital technologies in classrooms across the three education levels, which had almost doubled from 2011/2012, appeared to be greatest in countries located in Northern Europe. As for the more intense users of digital technologies, $19 \%, 15 \%$ and $30 \%$ of European students had teachers who used digital technologies in more than $75 \%$ of their lessons in primary, lower secondary and upper secondary schools, respectively [24].

The opinion of Fischer and others, who state that Learning Management is the backbone of eLearning in higher education, is being embraced. Numerous articles about learning management have been presented continuously at conferences (Fischer); it can be appreciated that a chance at education, which has become a component of a chance at life, cannot exist without e-learning [25].

Quacquarelli Symonds (QS) - one of the world's leading providers of services, analytics and insights into the global higher education sector-in their recent study called "The Impact of the Coronavirus on Global Higher Education", made during February and March 2020, reveal how 
prospective international students and higher education institutions are responding to this global health emergency [26]. In their exclusive prospective international student survey data, they had attracted approximately 11,000 respondents since mid-February. They asked "How do students feel about changes in educational delivery and the rise of online learning?", and until 26 March, $58 \%$ of prospective international students expressed some interest in studying for their degree online due to coronavirus restrictions, while only $42 \%$ stated that they had no interest in studying online. Additionally, $51 \%$ of the prospective international students surveyed said that they expected universities to move more of their lectures online. To another question regarding the challenges that institutions facing during this crisis, they received an answer that shows that universities are facing unprecedented challenges as a result of the coronavirus outbreak. Additionally, many universities are struggling to navigate this crisis while maintaining consistent course delivery, ensuring strong student recruitment numbers, and providing clear communication to staff and students. To the question "How are universities are embracing online learning?", the answers show that while $50 \%$ of the survey respondents had switched some of their scheduled courses online, this number is only set to increase as the coronavirus crisis continues.

\subsubsection{An Overview of the Educational Platforms in the Romanian Education System}

To be able to study the impact of eLearning in the Romanian education system during COVID-19, the authors analyzed the eLearning infrastructure in the Romanian Primary and Secondary Education system. Since the 2000s, in Romania, the eLearning software market, especially at the non-university level, has been dominated by SIVECO, a Romanian software company. The solution called AeL (Advanced eLearning), a SIVECO solution based on LMS scenarios, was implemented in the pre-university system in thousands of schools. This platform was implemented not only in the pre-university environment but also in other fields, an example being the implementation in the period 2010-2013 of a European project PODSDRU 59676, focused on eLearning at the University of Petroșani in partnership with SIVECO Romania SA. More recently, in the last 7 years, in the Romanian eLearning market, Ascedia SA should not be neglected, with their LMS LIVRESQ solution, delivered together with the use of free licenses for education offered by the technology giants Google and Microsoft (G Suite and Microsoft 365 A1) for the pre-university environment. Both companies have operated and are operating in partnership with the Romanian Ministry of Education and Research (MER).

Then, the authors analyzed eLearning in Romanian Higher or Academic Education. In the Romanian academic environment, the Learning Management System (LMS) platform, called Blackboard Learn, operates within Spiru Haret University (SHU), as a platform for teaching, collaborative work, testing and student management, and has been operational since 2006 . During the period 2006-2009, this platform was the basis for the fantastic rise-from 30,000 to 300,000 students in only 4 years, 2004-2008 - of the SHU and was perhaps one of the reasons why the SHU was not liquidated by the MER, but this aspect is another black hole of Romanian education [27].

In Romania, distance learning (DL) has often been based on eLearning platforms, and since 1995, when the DL education system appeared in Romania, by 2007, over half of Romanian universities (58\%) declared that they used eLearning solutions in didactic and non-didactic activities. Today, Romanian universities largely have eLearning platforms generally based on the most popular LMS-Moodle platform or on the most popular collaborative educational platforms designed by Microsoft and Google, which contain mail group modules, virtual classes, video conferencing, presentations and testing.

Because the study will be applied to the University of Petroșani, the authors analyzed the eLearning evolution at the University of Petroșani. The University of Petroșani started in 1998, the first study programs focused on a DL structure, and in 2011, an eLearning LMS platform called CourseMill was implemented. Today, in 2020, the existence of a small eLearning platform based on Moodle but not customized-with no virtual classes, without developed CMS content or scripting and also with no test modules-places University of Petrosani at the bottom of the ranking of Romanian universities in terms of virtual education [28]. This is happening in the conditions in which UPET has operated, 
since 2013, with a collaborative educational platform from Microsoft-Office 365 A1, which could be easily customized [29].

However, the question was always whether eLearning can replace classical education or can just support it. The approach of distance learning as an alternative or complementary way of doing education starts from ensuring and respecting quality criteria in terms of pedagogical, academic, administrative and technical aspects. The results of research to date, conducted in countries with a traditions in correspondence education, reveal that distance learning is as effective as traditional forms of education, if it is provided with a proper design [30]. The most difficult criteria to meet in an eLearning system are the quality criteria in which each element is equally important-Institutional support, Course development, Teaching and learning, Course structure, Support for faculty members and Evaluation.

There are digital education platforms developed by the most prestigious IT companies such as Google and Microsoft. The G Suite for Education package from Google contains modern digital tools that improve the teaching, learning and collaboration processes in the school by integrating new technologies in teaching and administrative activity (Figure 1). Microsoft for Education provides each student with the means to achieve better learning outcomes and teachers with the means to organize things in the classroom, from planning lessons to guiding students and monitoring grades, and keeping in constant touch with colleagues (Figure 2). The free G Suite for Education license, as well as the free Microsoft 365 A1 license, can be activated free of charge for any educational institution. The user account generated through this platform can be used for authentication in educational platforms developed by third parties, as long as they have implemented authentication with a Google or Microsoft account (Figures 3 and 4).

\section{G-Suite pentru Educație}

Conectează-te la Școala365 cu aplicațille Google pentru Educație și Microsoft office 365 pentru Educație: Digital Education.

Cu aplicațille din pachetul $G$ Suite for Education se pot îmbunătăți predarea, învătarea și colaborarea în întreaga școală.

70 de milioane de utilizatori din 190 de țări folosesc aplicațille Google pentru educație. Peste 20 milioane de profesori și elevi din întreaga lume folosesc aplicatia Google Classroom.

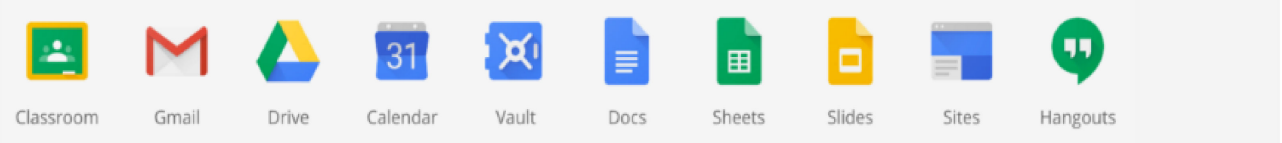

Figure 1. School 365 Platform for Education G-Suite for Education [31].

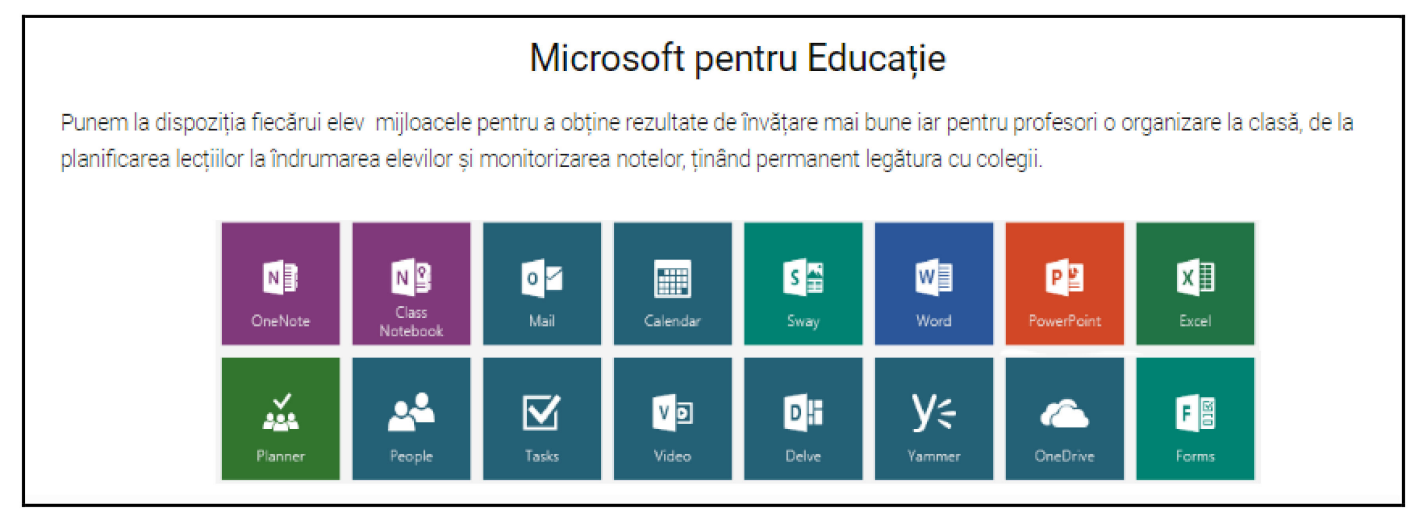

Figure 2. School 365 Platform for Education Microsoft for Education [31]. 


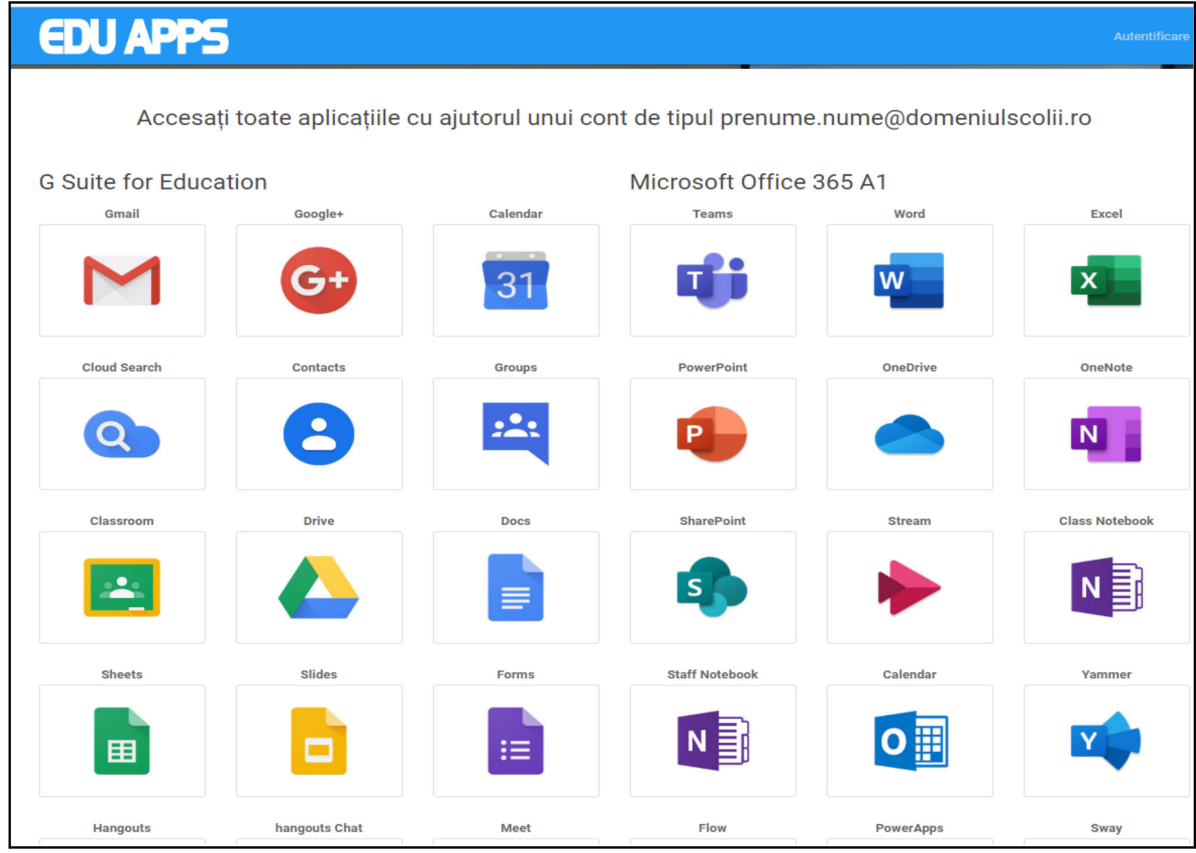

Figure 3. Class of the Future license package [32].

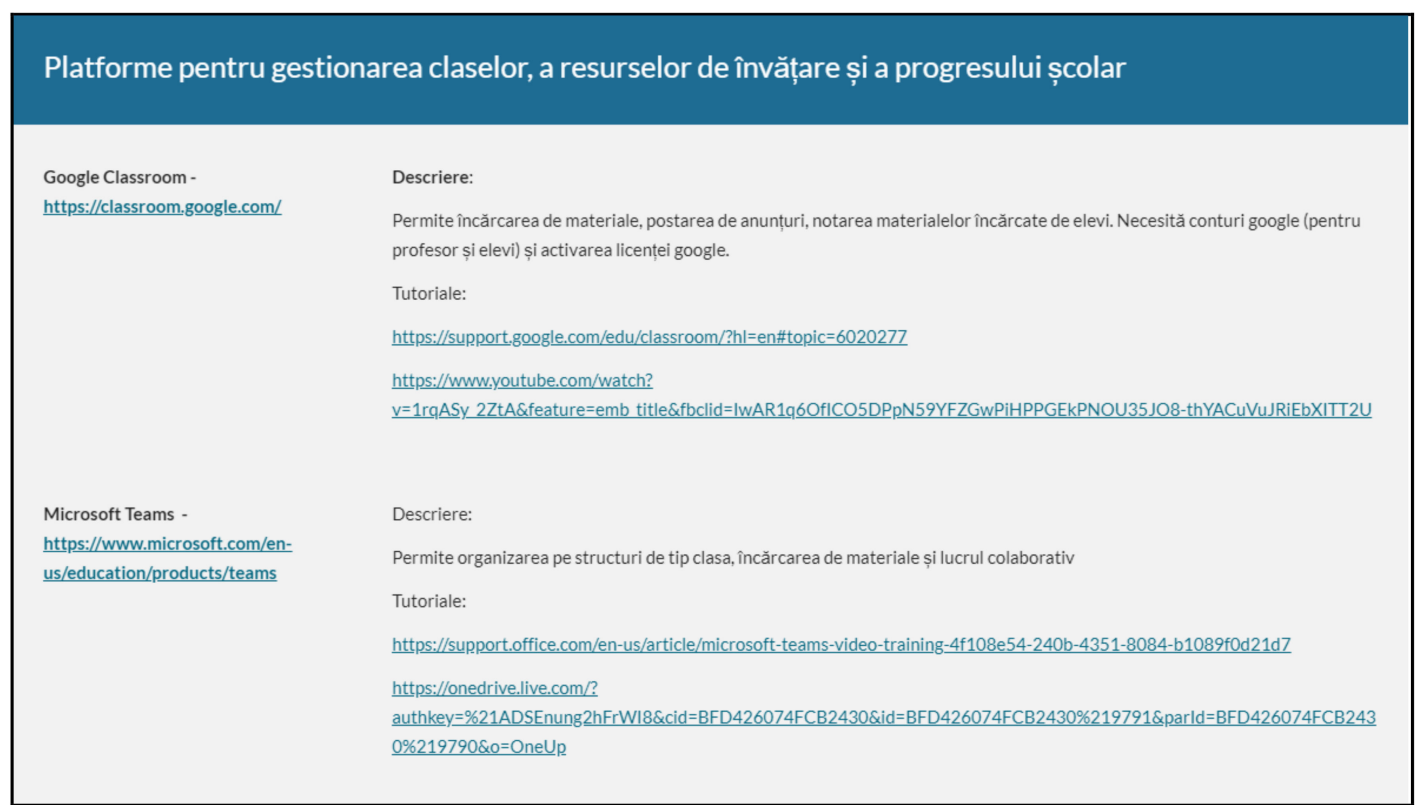

Figure 4. Platforms for managing classes, learning resources and school progress [33].

In this context, Romanian universities have adopted a mixed strategy for implementing virtual education in the context of the attractive educational offers from Microsoft and Google, on the basis of the existence of specializations authorized for distance learning or part-time education but also using their own platforms already developed. Thus, Gheorghe Asachi University of Iași uses both educational platforms, the Technical University of Cluj Napoca and Politehnica Bucharest chose the Microsoft platform Microsoft 365 A1, Lucian Blaga University of Sibiu and the University of Craiova opted for Google G Suite, Politehnica Timișoara opted for its own virtual campus variant, and the University from Oradea and Transilvania University of Brașov have chosen to develop online courses on a Moodle platform [34-41]. 


\subsection{Designing an eLearning Platform at the University of Petroșani, Using Microsoft 365 A1 Licence}

\subsubsection{Teacher Training for Online Education}

As Eduard Edelhauser presented in his habilitation thesis [42] in 2014, in the chapter "Modern Methods of Education and Training-Designing and Implementing of eLearning Platforms", the authors have been concerned with eLearning during three research projects: POSDRU 39352 (2008)—Designing and Implementing an eLearning Platform for an e-Master at the University of Petrosani in the Field of Project Management (PM) and Information Technology Systems (ITS), and POSDRU 59676 (2010-2013)_Designing an eLearning Portal and CC (2013) Implementation of Microsoft Office 365 at the University of Petroșani; eLearning was present but not necessary implemented [43]. Then, in the POCU 122596 project called "Education, a chance for the Jiu Valley!", Eduard Edelhauser had implemented a postgraduate program Computer Aided Training and Online Educational Platforms, in which the authors have trained over 60 professors of the University of Petrosani in the eLearning field [44] (Figure 5).

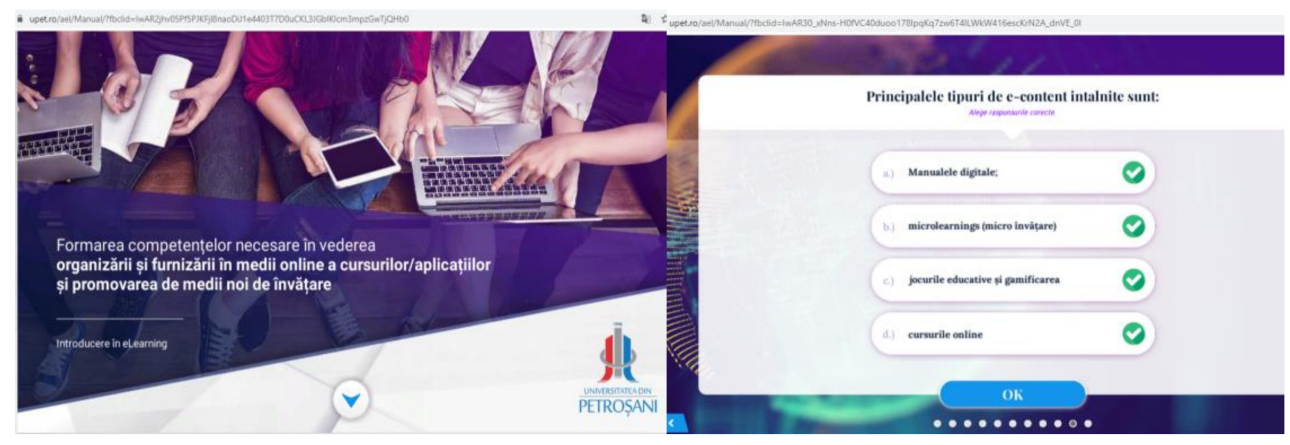

Figure 5. Computer Aided Training and Online Educational Platforms POCU 122596 [44].

\subsubsection{Implementing eLearning Courses on a Microsoft Platform}

The implementation of Office 365 A1 at the University of Petroșani in the year 2013 was based on the hardware servers based on an Active Directory, and that required the creation of several OUs (Organizational Units), namely ALL_GROUPS, in which there are four other OUs, and each of them contains a "security group" that we have used as email address groups that contain several users; we will provide detail below related to this. Teachers were added to the OU with STAFF and students to IME, MINE and SCIENCE. For example, to create a user for an IMIT teacher, one right-clicks on the IMIT OU in FRAMES, chooses NEW and then USER, types in the first name and last name, and for the user logon name enters together the first name and last name of the teacher, after which NEXT is typed; in the next window, one has to define any password, no matter what, because it will have to be defined again in Office 365. A mail group was created as follows: From the AD console (Active Directory) go to the OU "ALL_GROUPS", right-click on the OU where you want to create the new group and choose NEW-GROUP, and type in the desired name; for group scope, leave global checked, and as the group type, choose security, then type OK. Then, a number of parameters from the properties of the newly created group need to be added so that this mail group can be used in Office 365 as well. Thus, for the group properties, in the "general" tab, there is an email field where the desired email address of the respective group must be added. The second setting to be made is to add the group's email address to the "display Name" field in the "Attribute Editor" table. After making these settings, we must not forget to force synchronization to Office 365; otherwise, we will have to wait for up to $3 \mathrm{~h}$ to update in the cloud. At this point, things are completely moved to the cloud, as the university no longer needs the local component. To add new users, the procedure is accessible to the administrator, who can add one or more users at a time.

In this chapter, the authors present how Microsoft 365 could be implemented at the University of Petroșani as a collaborative educational platform, with UPET having 3500 licenses of Microsoft 365 
A1 for all the teachers and students. The authors have exemplified all the stages of implementing an eLearning platform for two disciplines called Applied Informatics and Assisted Drawing, taught as specializations of the Faculty of Mines by Professors Lupu Lucian and Eduard Edelhauser [45].

Using the platform for mixed teaching activity.

The use of the resources available on the Microsoft 365 platform is not limited to a strictly remote activity, in which students do not have a class presence; continuous communication and collaborative work ensures a better involvement in the educational process. Thus, as is done in exclusive online situations and in the mixed regime, the student in the virtual classroom is the central element (Figure 6).

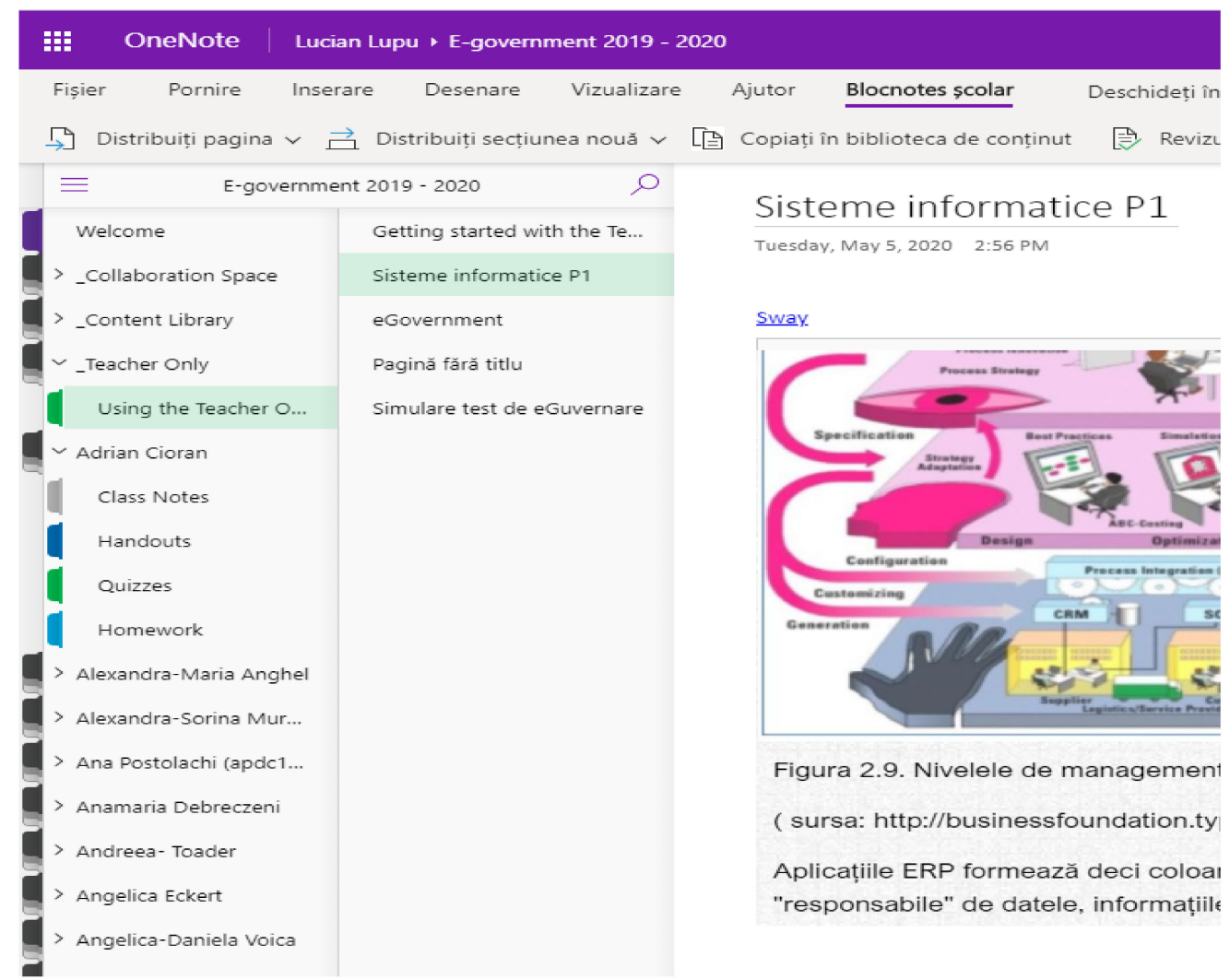

Figure 6. The structure of a virtual class in OneNote Class Notebook.

The way in which a classroom could be combined with a virtual activity in relation to the student is described in the following. Prior to each course or laboratory, an event is created, using the Calendar application, through which all the targeted students are assigned, then to the students must be sent the subject of the meeting, the place where the course will take place, the time, and other requirements. Students, in class, access their own account, in order to use the available resources. If the student has to do essays or meet other requirements of the nature of the individual work, they can present their work, having it in front of them (Figure 7).

In the classroom, the practical activity, which takes place on the computers from the laboratory, is loaded individually by each student, in the dedicated section, thus offering the student the comfort of the activity and the private nature of their work.

Use of the platform for teaching activities exclusively online.

There are situations in which it is impossible for the student to be present in the classroom, whether due to the nature of the course or exceptional circumstances. In these situations, at the time of creating the event, it is established that the meeting should be done using the Teams application. 
It should be noted that in the Microsoft 365 platform, the two applications Calendar and Teams have the common time element, so an event is created in the Calendar and a meeting is created in Teams. The advantages offered by this way of working are multiple, mainly related to computer security and control of the course. The organizer-in our case, the teacher-is in a situation where they present to students the course, for which they can use audio, video, and screen sharing or more directly use Teams or the Whiteboard application, through which virtually all participants have access to the virtual board to write. Online meetings are presented by teachers, and they provide students with support information sets, the platform offering - in addition to the already traditional Word, Excel, PowerPoint (now online)-a significant number of very attractive applications, such as Sway, Video, SharePoint or even Power Automate (Figure 8).
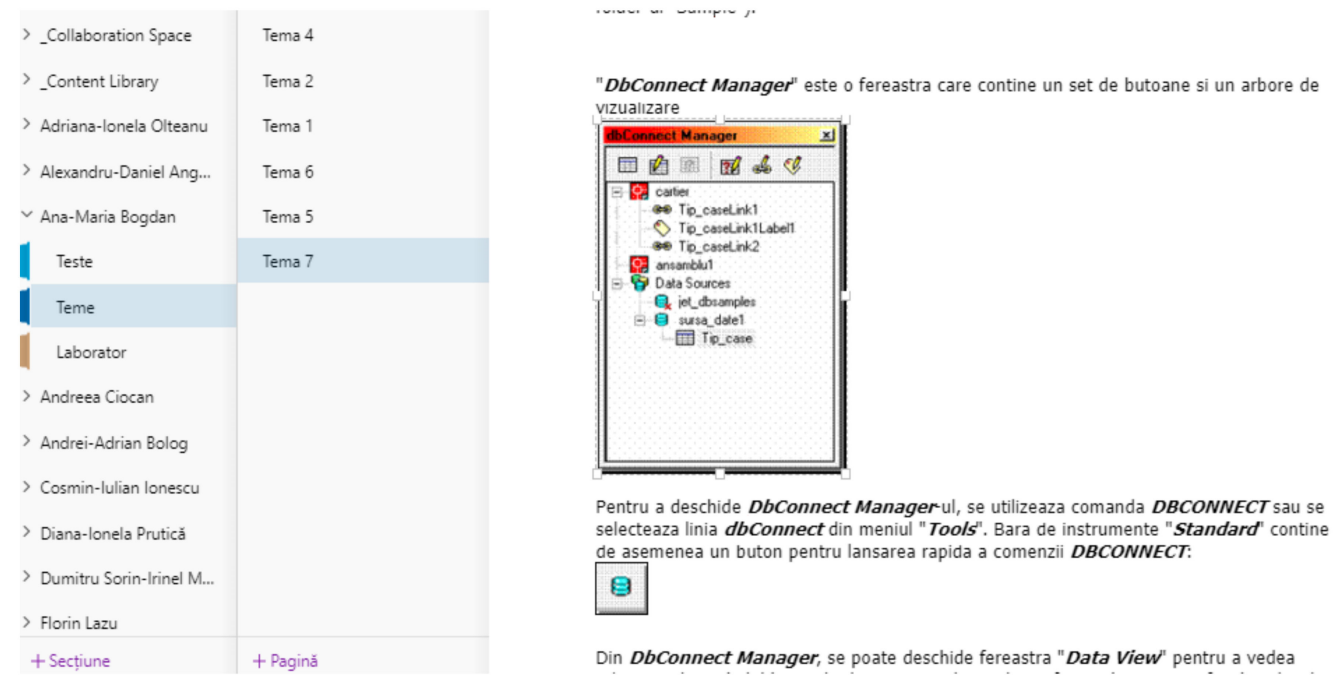

Figure 7. Structure of the student's Virtual Bank sections.

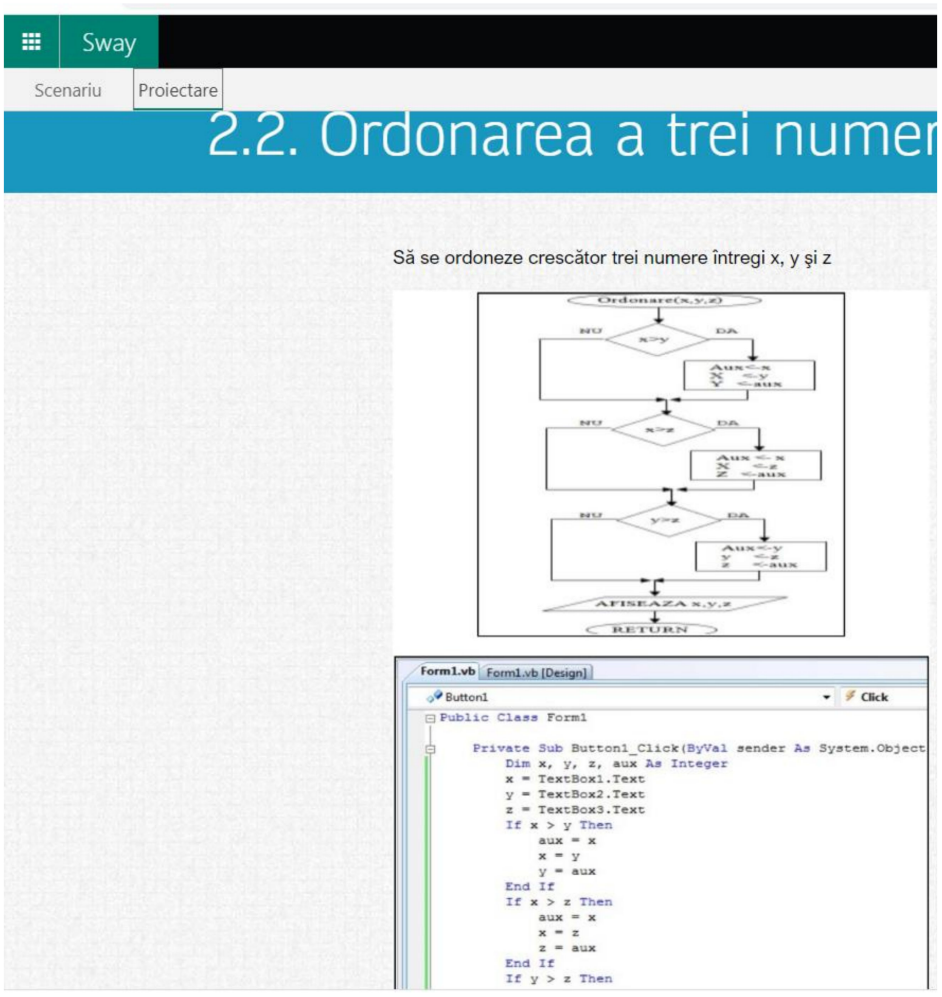

Figure 8. Sway presentation example. 
Checking students' knowledge using the Microsoft 365 platform is possible and also represents a great challenge for the teacher. The application that allows an online exam is called Forms, and it is integrated very well with OneNote Class Notebook (Figure 9).

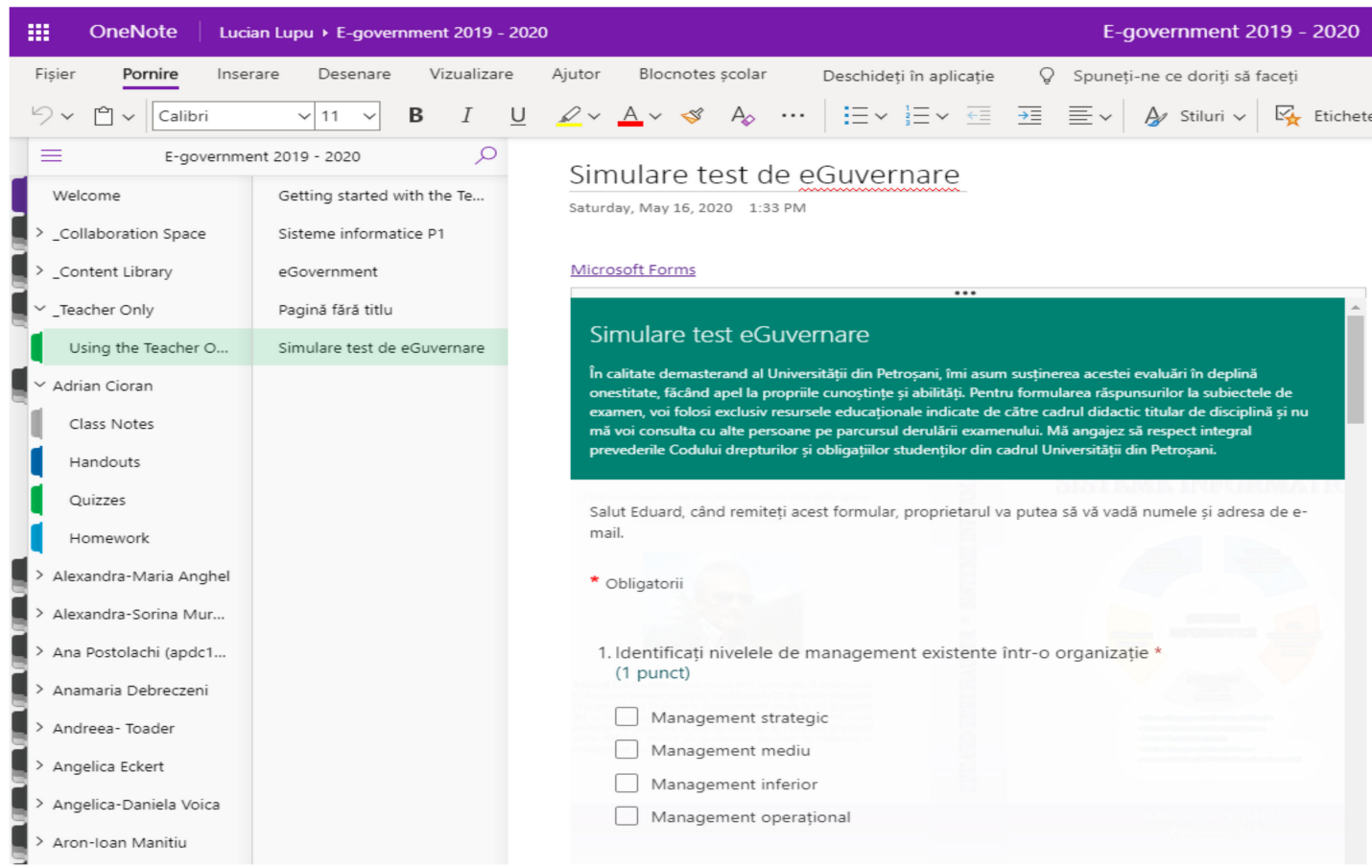

Figure 9. Forms integration with OneNote Class Notebook.

The Forms application allows the completion of questionnaires of a medium complexity, allowing the teacher to impose completion rules, time limits in terms of the interval in which the form can be completed, and the anonymity or identification of the respondent (Figure 10).

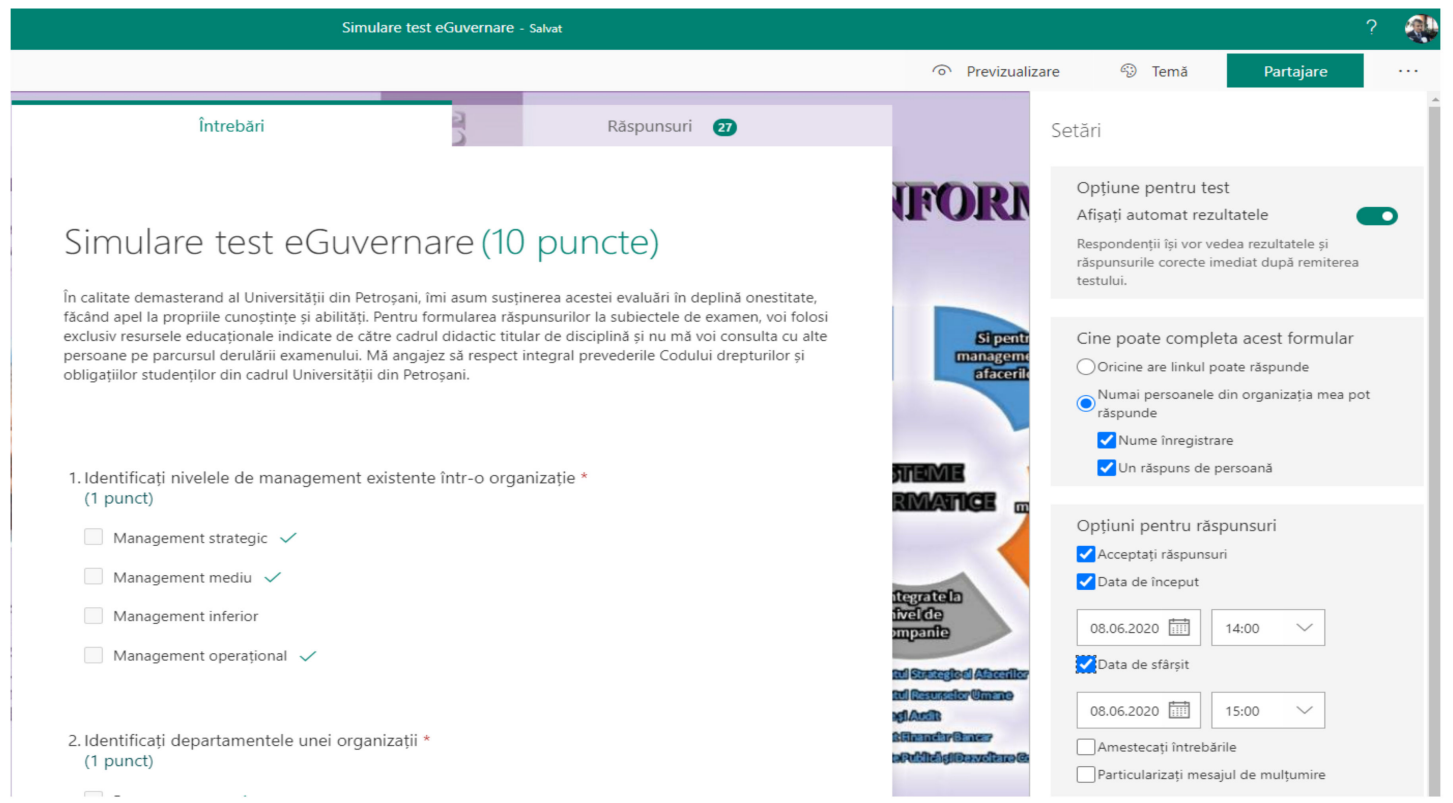

Figure 10. Student testing questionnaire—creation and configuration interface.

After completion, the teacher has the opportunity to check the answers received, individually or globally, to provide respondents with comments and to moderate. At the end, the teacher can complete 
an overview of the answers to the questionnaire and also an individual evaluation of the questionnaire answers with the possibility of sending details to the respondent, general for the whole questionnaire or related to each question. At the end of the evaluation, the teacher has the possibility to publish the evaluation performed, using the option "Post scores".

\subsection{Methodology}

The study conducted at the University of Petrosani gave the authors some answers to the question "is Romania prepared for eLearning during the 2019-2020 coronavirus pandemic?". By virtue of the questionnaire, the authors achieved the results. In order to analyze the statistical connections, they used correlation analysis for the intensity of the connections between the variables and regression analysis to estimate the value of a dependent variable (effect) considering the values of other independent variables (causes). Additionally, the authors carried out a multiple regression analysis in order to identify the effect that virtual education has on the University of Petroșani students. The instrument used for collecting data was a quantitative questionnaire and was used as a technique for investigating the students of the University of Petrosani undertaking bachelor and master studies in the academic year 2019-2020. The questionnaire used was focused on the level of online education using 19 questions.

\subsubsection{Respondents}

The study set its sights on over 209 students from the University of Petroșani, and data were collected during the survey period, which was 24 h, between 29 April 2020 at 1 p.m. and 30 April 2020 at 1 p.m. The survey led the authors to identify, based on the processing of the data gathered through the questionnaires and on the statistical data, the existence of some trends in online education, trends that will offer the possibility of preparing a set of measures that we will propose to the decision-makers at the university and at the national ministerial level. In the second part of the investigation, the results of the questionnaire were confirmed by the data offered at the end of May 2020 by the Dean's Office of the two faculties investigated: data collected by the Dean's Office regarding the teacher options during May, regarding the online examination tools proposed for the June 2020 exam session. This happened even if the university leadership would have previously opted for a face-to-face testing or for the use of a poorly configured Moodle-based eLearning platform.

\subsubsection{Limitations of the Study}

However, there are certainly limitations regarding the representativeness of the sample, because the authors distributed this questionnaire mainly to the groups of students they work with in teaching and projects. According to the way in which the questionnaire was distributed, the students who answered were most likely part of at least $70 \%$ of the 100 students that the authors see weekly in online courses and the almost 100 active students involved in their POCU 122596 project; the distribution of the questionnaire was mainly done in the student social media groups.

The number of answers received, from 209 students, compared to the total number of 3414 students of the university, can be considered unrepresentative (6\%). However, if it is considered that this Microsoft Forms questionnaire composed of 19 questions was distributed in only 15 Facebook University of Petrosani student groups, out of a possible total of 60-80 such groups, in the context that there is not a situation in this sense at the university level, the study appears to be more and more representative.

Because the authors' teaching activity is directed towards the bachelor's programs of the Faculty of Mines (597 students), the master's programs of the Faculty of Sciences (366 master students), and the European project POCU 122596 - which they coordinate as project managers and is addressed to students undertaking undergraduate studies in the Faculty of Mines and students undertaking master's studies in the Faculties of Mines and Sciences in their final years (629 master's students) - the percentage of answers could increase to $16 \%$ (second part of Table 1 ). 
Table 1. Limitations of the study.

\begin{tabular}{|c|c|c|c|c|c|}
\hline \multicolumn{4}{|c|}{$\begin{array}{l}\text { University of Petroșani } \\
\text { (Total Number of Students) }\end{array}$} & \multirow[t]{2}{*}{$\begin{array}{c}\text { Number of } \\
\text { Respondent Students }\end{array}$} & \multirow[t]{2}{*}{$\%$} \\
\hline Faculty/Level & Undergraduate & Master Degree & Total & & \\
\hline Mining & 597 & 263 & 860 & 65 & $8 \%$ \\
\hline $\begin{array}{l}\text { Mechanical and Electrical } \\
\text { Engineering }\end{array}$ & 1113 & 244 & 1357 & 31 & $2 \%$ \\
\hline Science & 832 & 366 & 1198 & 113 & $9 \%$ \\
\hline Total & 2542 & 873 & 3415 & 209 & $6 \%$ \\
\hline respondent & 121 & 88 & 209 & & \\
\hline \multirow[t]{2}{*}{$\%$} & $5 \%$ & $10 \%$ & $6 \%$ & & \\
\hline & \multicolumn{2}{|c|}{$\begin{array}{l}\text { University of Petrossani } \\
\text { (Students Investigated) }\end{array}$} & & $\begin{array}{c}\text { Number of } \\
\text { Respondent Students }\end{array}$ & $\%$ \\
\hline Faculty/Level & Undergraduate & Master Degree & Total & & \\
\hline Mining & 597 & 263 & 860 & 65 & $8 \%$ \\
\hline $\begin{array}{l}\text { Mechanical and Electrical } \\
\text { Engineering }\end{array}$ & 75 & & 75 & 31 & $41 \%$ \\
\hline Science & & 366 & 366 & 113 & $31 \%$ \\
\hline Total & 672 & 629 & 1301 & 209 & $16 \%$ \\
\hline respondent & 121 & 88 & 209 & & \\
\hline$\%$ & $18 \%$ & $14 \%$ & $16 \%$ & & \\
\hline
\end{tabular}

This is possible because the authors have reported the answers for the total number of students with a priority for the two faculties in which the authors carry out teaching activities, and therefore, the percentage of answers increases from 5-10\% (121 respondents out of a total of 2542 undergraduate students and 88 respondents out of a total of 873 master students) to $14-18 \%$ upon eliminating the un-investigated students, which is now indisputably representative.

\subsubsection{Validity of the Study}

Data were collected only from a single university, for which authors have demonstrated the validity of the study in Chapter 2.4.2., demonstrating that 209 students are representative for this university; the University of Petrosani could be considered representative for the whole Romanian education system in the field of eLearning during the COVID-19 Pandemic, based on the following arguments.

First of all, the authors consider that the study is representative for the Romanian eLearning system based on the fact that primary, secondary and high schools and also small universities represent $88.80 \%$ of the pupils and students involved in the Romanian education system from the total of 2,926,168 pupils and students enrolled in the Romanian education system in the 2019-2020 academic year.

Then, from government sources, such as the Romanian Ministry Education and Research, is offered information during the COVID-19 pandemic crisis about the eLearning tools used for primary, secondary and high schools. These unsophisticated tools, used here, are similar to the eLearning tools used in universities with no expertise in eLearning, such as the University of Petrosani. This occurs because, unfortunately, schools and small universities started the massive implementation and use of eLearning only during COVID-19 crisis.

In the end, the authors conclude that there exists a similarity of behavior in the field of eLearning for schools with no expertise in eLearning education, and this allow the authors the opportunity to extrapolate the results from the University of Petrosani and also offers the possibility of generalizing the conclusions of the study for the whole Romanian education system, but only in the field of eLearning during the COVID-19 Pandemic. 


\section{Results}

\subsection{Graphical Results for the Research Based on the Questionnaire}

An important question of the survey was focused on the information that shows that at the University of Petroșani, the eLearning concept appeared to be relevant only after the beginning of the coronavirus pandemic (Figure 11).

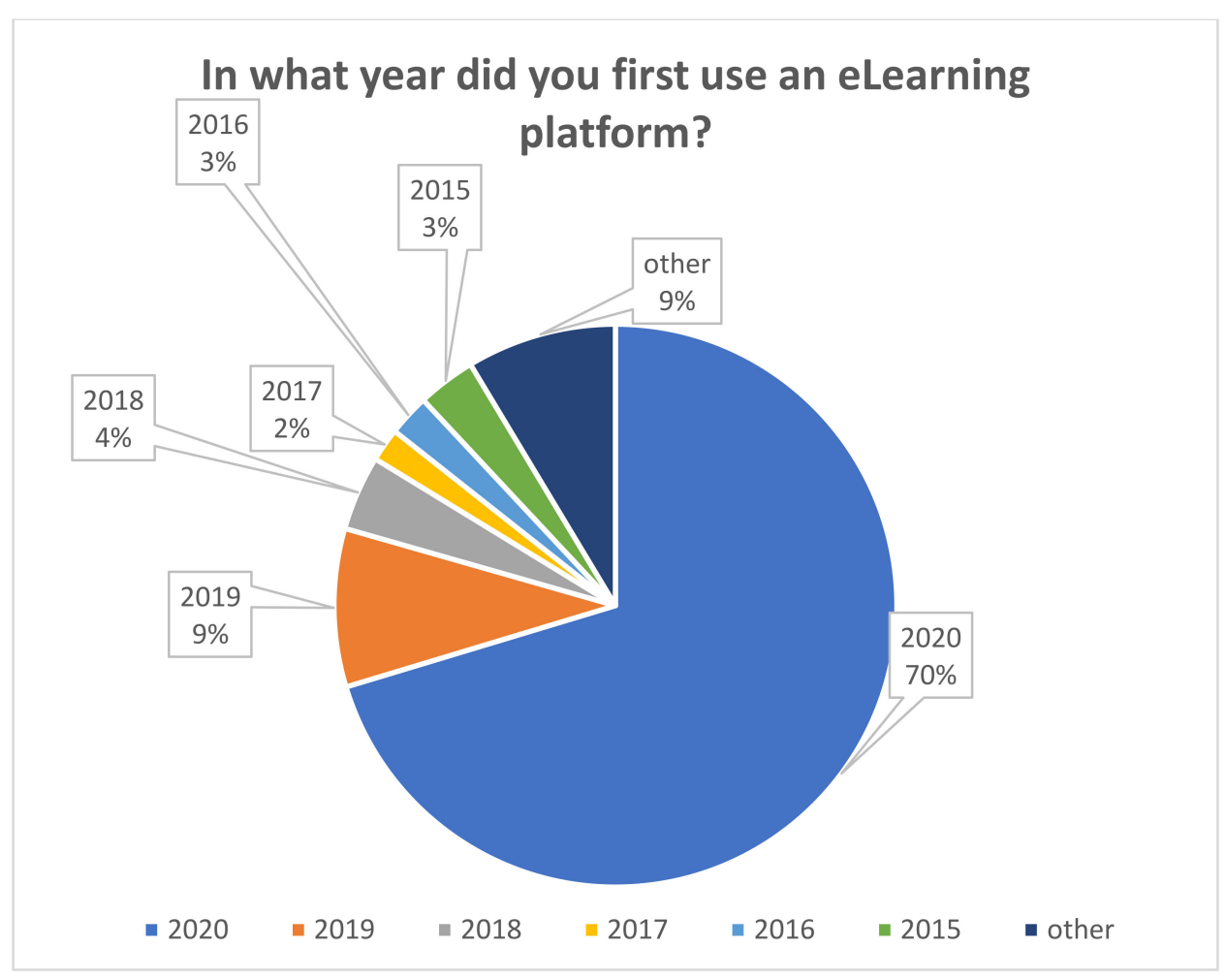

Figure 11. Q1, "In what year did you first use an eLearning platform or did you go through an education-focused video conferencing session?".

One other relevant question shows that students have quickly migrated to online courses (Figure 12).

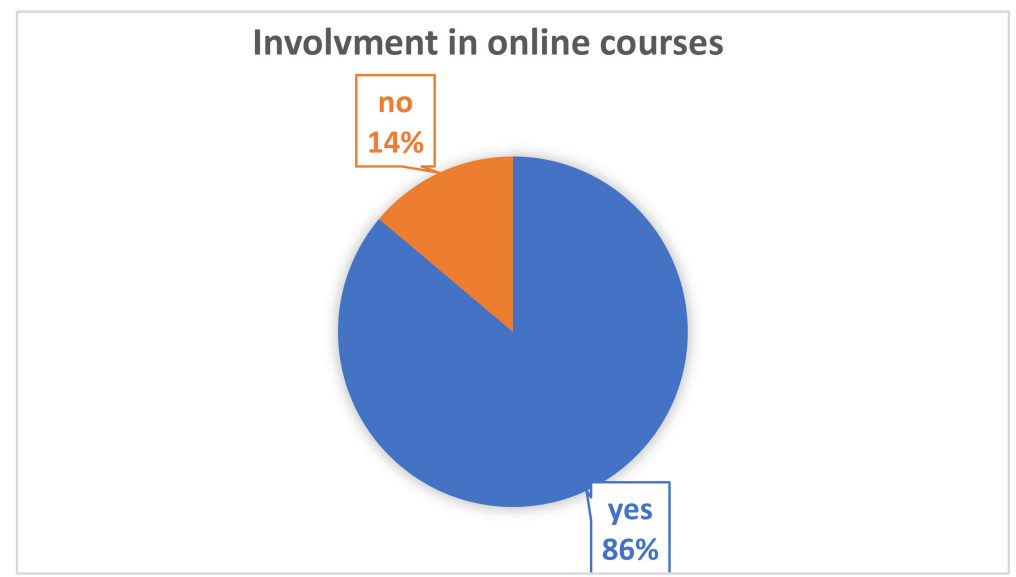

Figure 12. Q2, “Did you attend online courses between 16 March 2020 and 30th April 2020?".

The involvement of the students in online courses is very difficult to evaluate, because some students can perceive that sending an email could be considered the use of an eLearning tool, or even 
WhatsApp can be perceived as an eLearning tool. Thus, even if they answered at a rate of $86 \%$ that they were involved in eLearning, this is an inaccurate result because it was demonstrated in Q11, Q12 and Q13 that student involvement in eLearning was lower.

Another important result of the study was that the authors concluded that laptops and smart phones are the most used devices by the students for online courses. Using a laptop for eLearning is a normal state, but a smart phone is not necessarily a device for eLearning, even if it can be used for attending a video conference or for taking an exam, using a form (Figure 13).

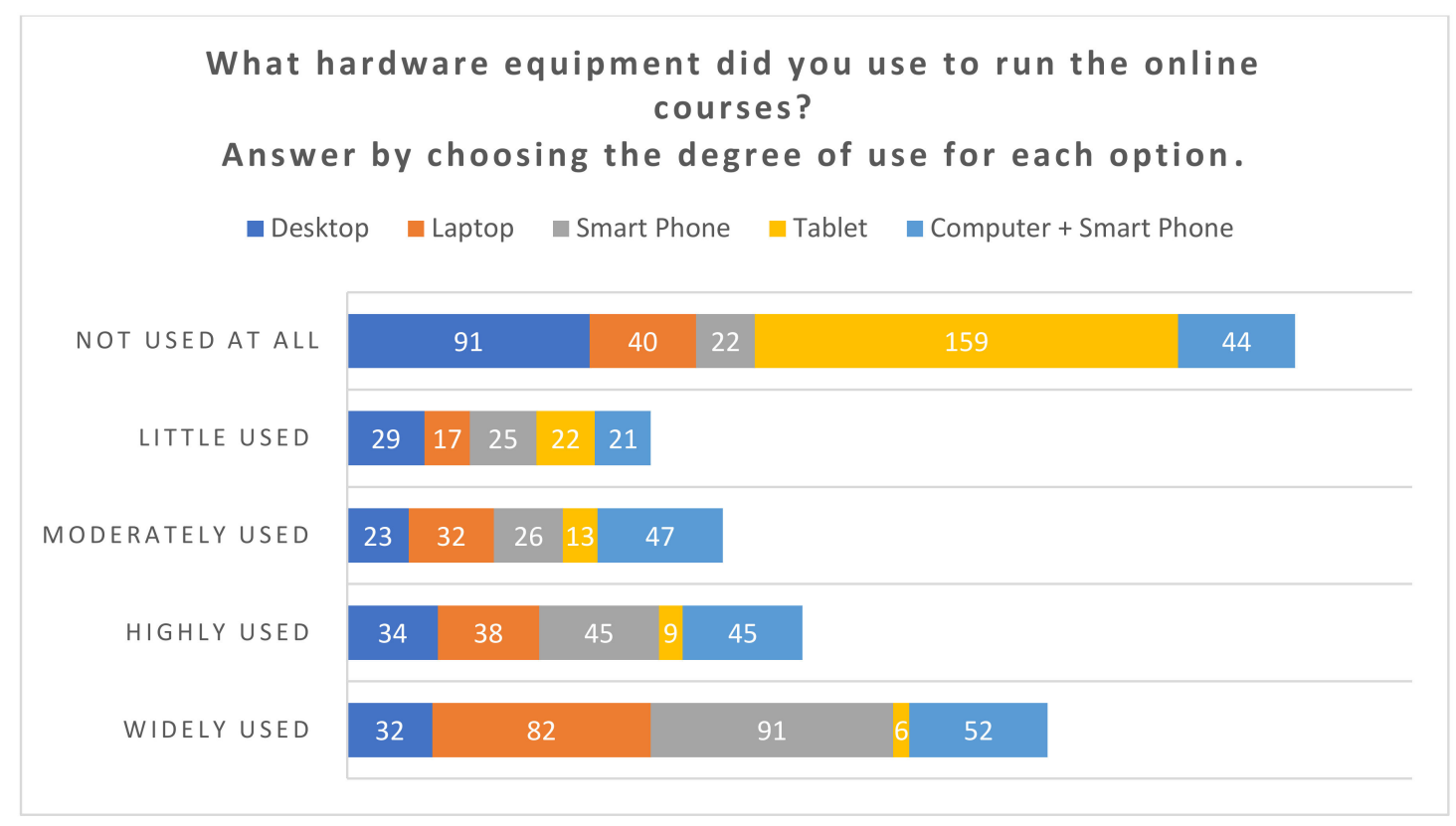

Figure 13. Q3, "What hardware equipment did you use to attend the online courses? Answer by choosing the degree of use for each option (number of students).".

From the investigation, the authors have noticed that even the number of students that attended for 1 or $2 \mathrm{~h}$ per day seems to have grown for online courses; in fact, these are the students that attended 5 or $6 \mathrm{~h}$ of classic courses, and the courses were probably not held. Thus, the presence at the eLearning classes is lower than that at the classic classes, and also the drop-out rate is high in the eLearning classes (Table 2).

Table 2. Student attendance for classic or online classes by hours per day.

\begin{tabular}{ccc}
\hline Hours of Courses/Day & Online & Classic \\
\hline $\mathbf{0}$ & 9 & 16 \\
$\mathbf{1}$ & 54 & 34 \\
$\mathbf{2}$ & 83 & 39 \\
$\mathbf{3}$ & 22 & 18 \\
$\mathbf{4}$ & 23 & 25 \\
$\mathbf{5}$ & 5 & 12 \\
$\mathbf{6}$ & 8 & 44 \\
More Than $\mathbf{6}$ & 5 & 21 \\
\hline
\end{tabular}

The outer circle represents the classic classes, and the inner circle, the online classes, and the numbers 0-6 and more than 6 represent the numbers of hours per day. On average, the number of hours for classic courses per day for the investigated students was 3.70, while the average number of online hours per day was only 2.43. Additionally, the graphic shows a high density for $2 \mathrm{~h}$ per day in the online method, while for the classic method, the density is set at $6 \mathrm{~h}$ per day (Figure 14). 


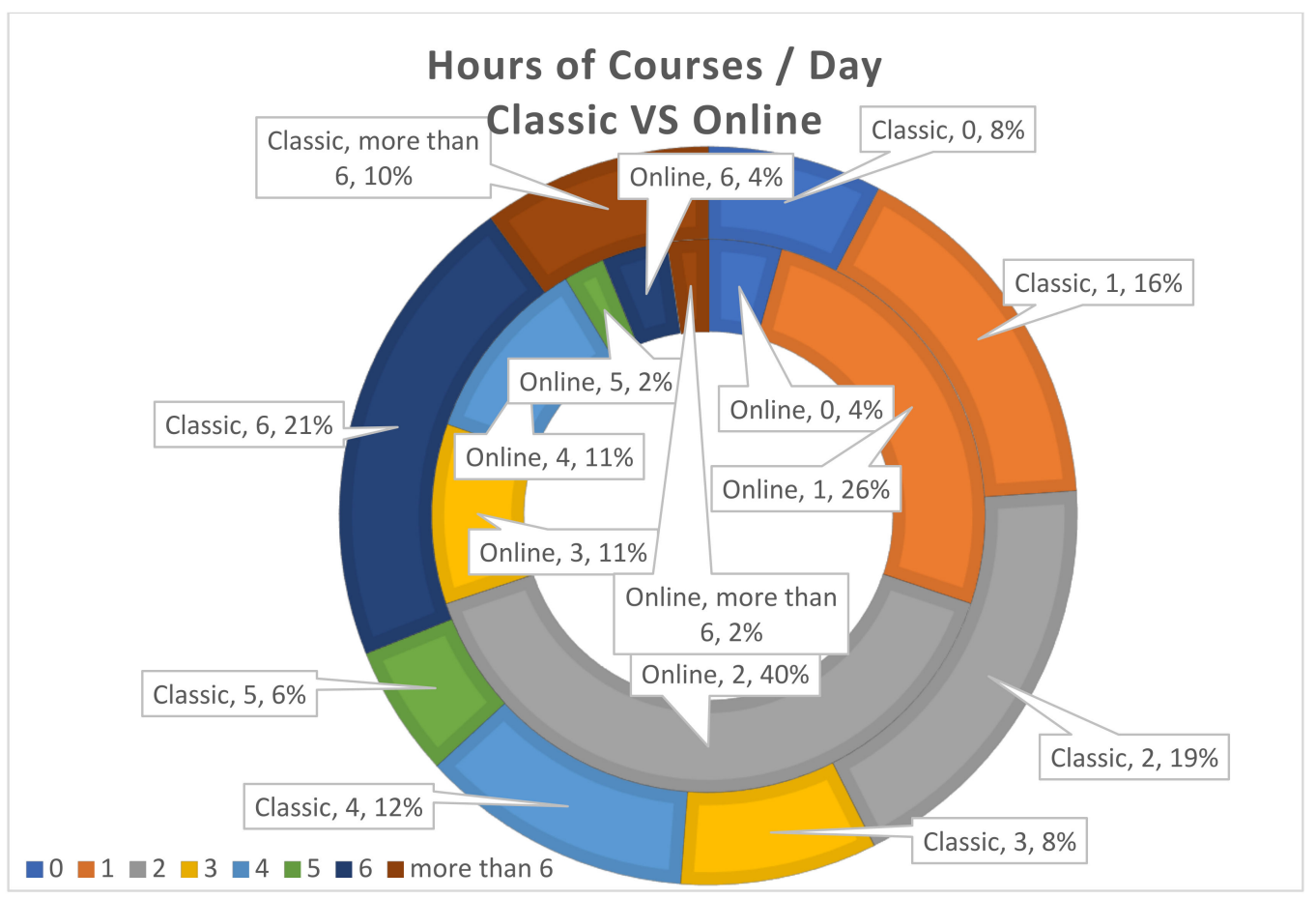

Figure 14. Q6, "What was the number of hours per day dedicated to your online courses during the state of emergency?", and Q7, "What was the number of hours per day dedicated to conducting the courses in the classic format by you in the period prior to the declaration of the state of emergency?".

The number of respondents that chose email as a communication system or method (119) and as a widely used device or method demonstrates that there was not an eLearning platform implemented, and the courses were mainly sent by email. The second preference for the student is a social media platform, Facebook, for communication, even if Facebook has nothing to do with eLearning (Figure 15).

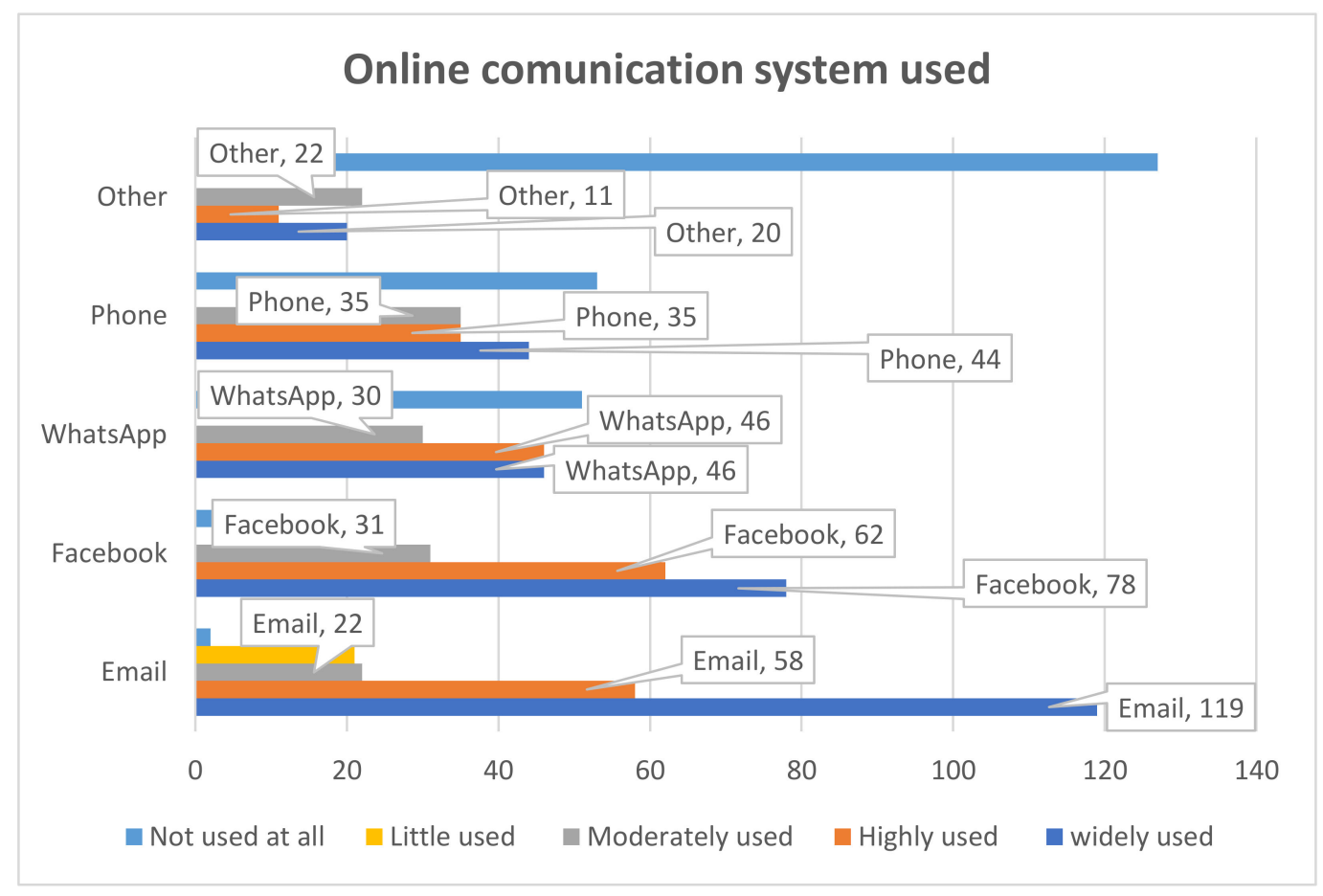

Figure 15. Q8, "What online communication system did you mainly use to communicate with the teacher? Answer by choosing the degree of use for each option (number of students).". 
One of the most powerful tools for eLearning is the virtual class, which sets the presence; the dialog; and the use of the Handout, Class Notes, Homework and Quizzes tools for teachers and students. Even though 30 students answered that they used a Google or Microsoft classroom (Figure 16), in the authors conducted investigation at the end of April, but at the end of May, they received an official statement offered by the Dean's Office of two faculties of three, which stated that virtual classes were used only at a $14 \%$ level in the exams for the Faculty of Mining and were not used by the Faculty of Science.

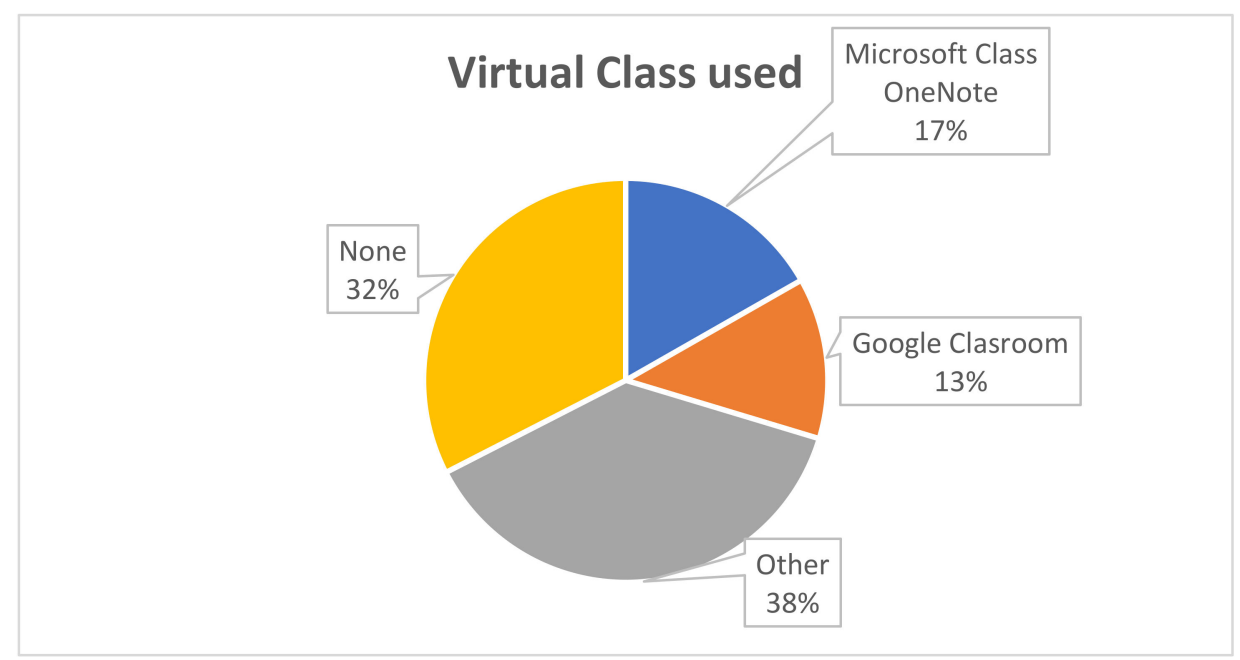

Figure 16. Q11, “Were the virtual classes used for the seminar or project classes? If so, specify which".

During the semester, in April and May, 48\% of the students used the Quizzes such as Forms for testing (Figure 17), and these results of the investigation conducted at the end of April were confirmed at the end of May when the authors received official information on the situation; they demonstrated that online tests were used at $43 \%$ and $48 \%$ levels during the exams for the Faculty of Science and the Faculty of Mining, respectively.

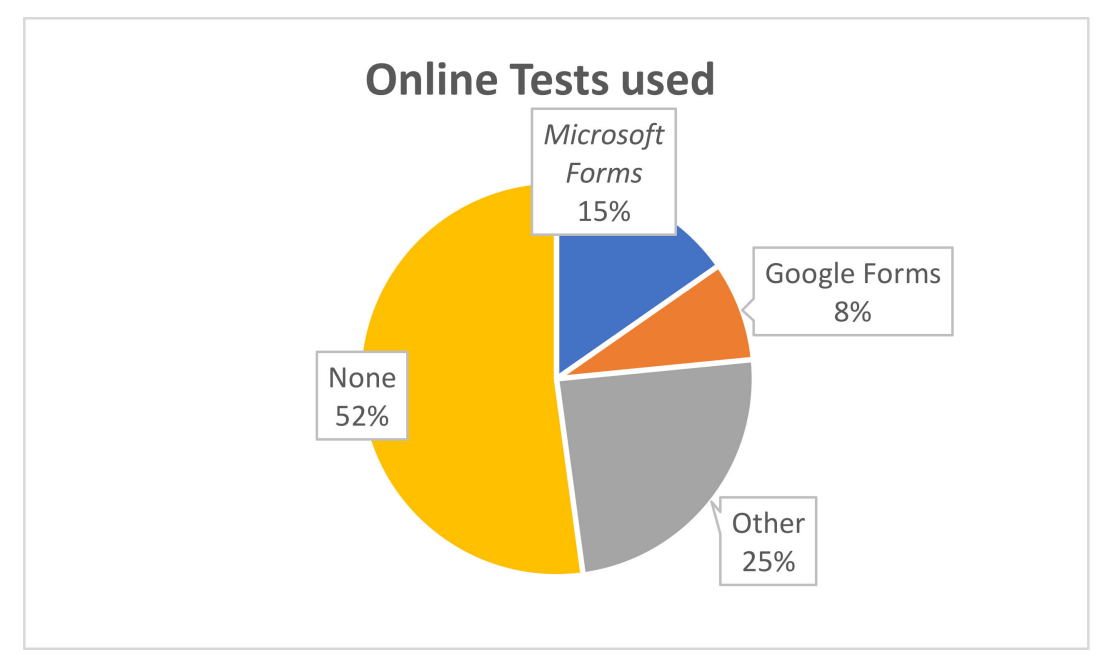

Figure 17. Q12, “Were predefined online tests used for online testing? If so, specify which.”.

The tools for video conferencing from the virtual classes were not used in general, users in Romania preferring the Zoom software for the online activities during the COVID-19 crisis because it is free and easy to use (Figure 18). 


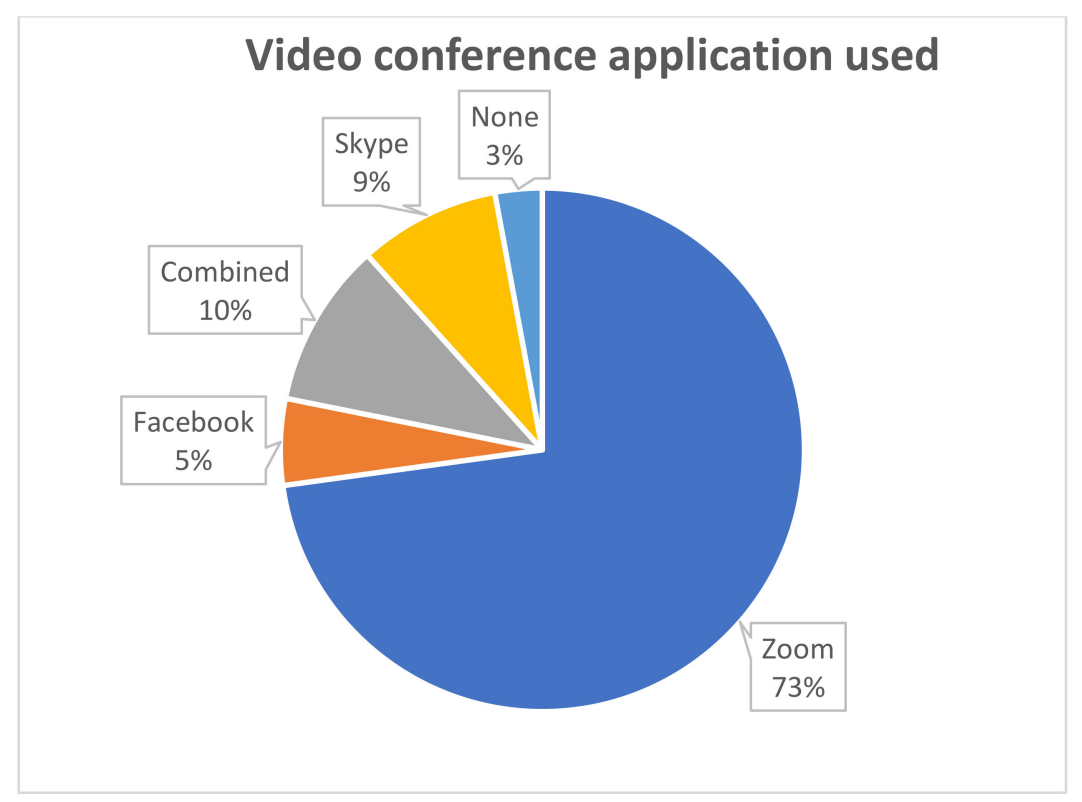

Figure 18. Q13, "What program did you use during the video conferencing courses?".

Because there has been no serious concern from the university for online teacher training, only $50 \%$ of the courses actually take place online. On average, the number of online courses (from a maximum of seven) for the investigated students was 3.45 (Q14), so only three teachers out of seven have efficiently used online courses. (1, 2 and 3-blue, orange and grey) (Figure 19).

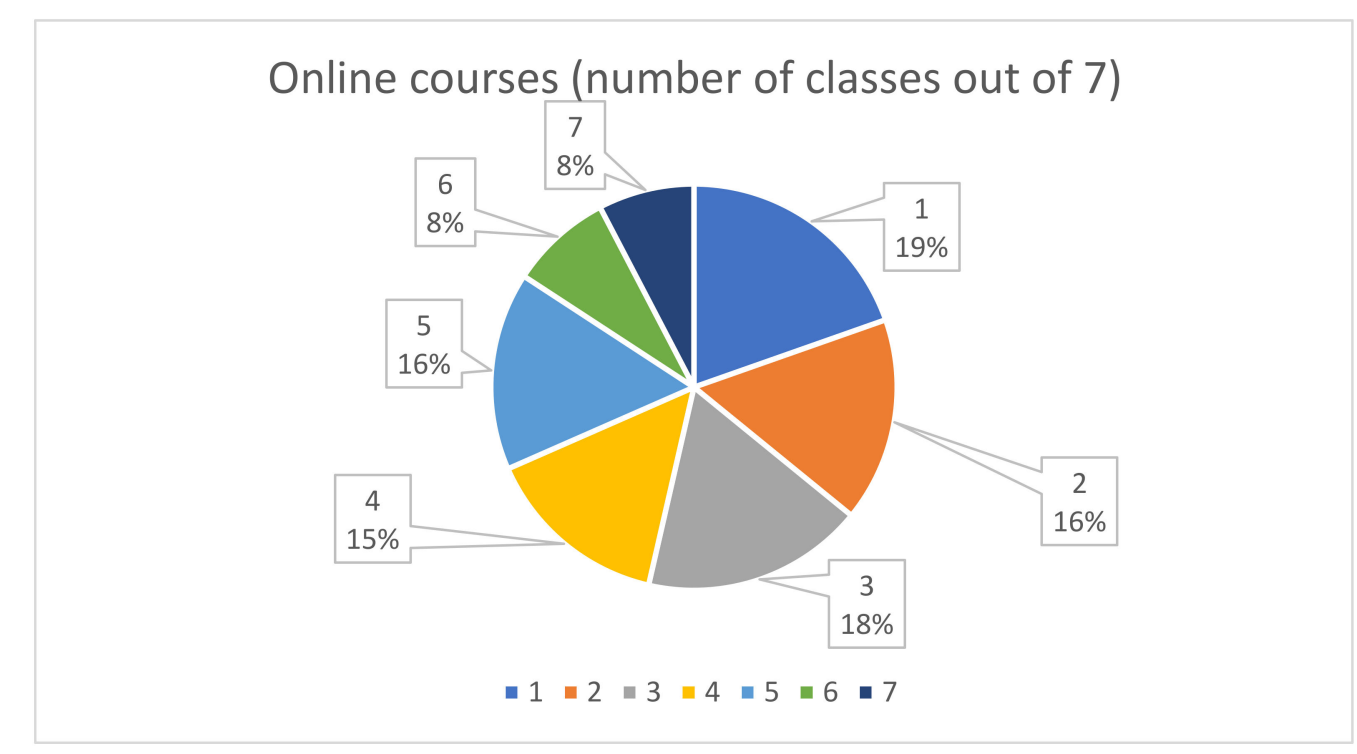

Figure 19. Q14, "Out of the total of 5-7 study disciplines allocated to the 2nd semester of the academic year 2019-2020, for how many of them did you use online courses?".

The average number of courses that were held using a videoconferencing technique was only 2.20 (Q15), which represents only $30 \%$ of the seven classes set in curricula, so only one of three teachers used the video conferencing tool. It is apparent that only for 1-2 classes were video conferencing used (1 and 2-blue and orange) (Figure 20). 


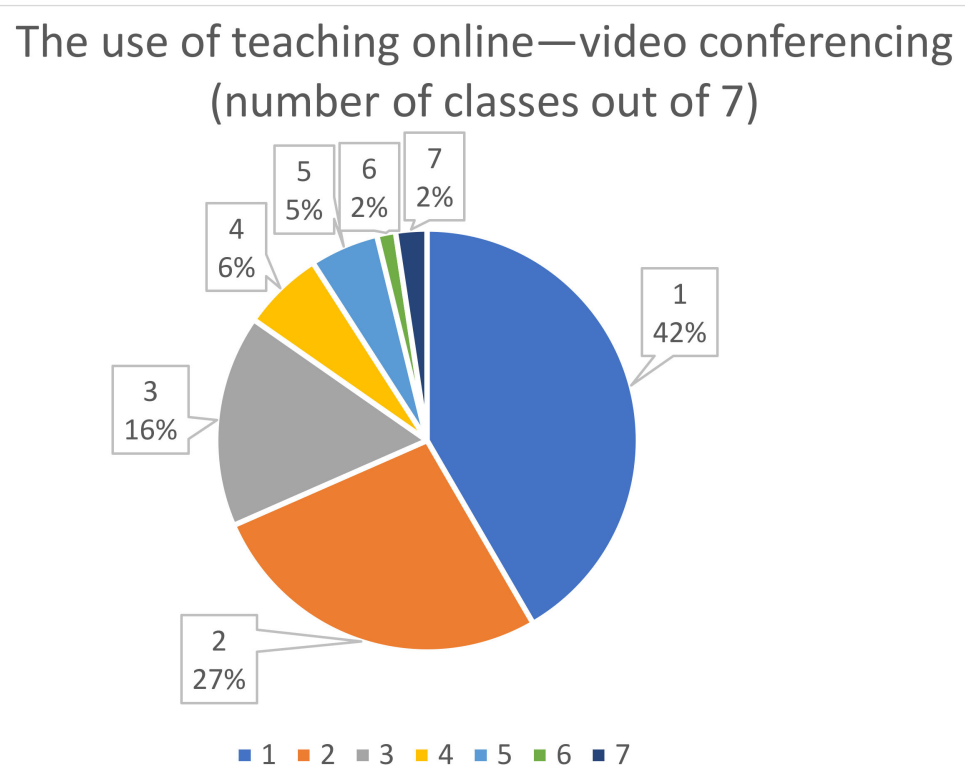

Figure 20. Q15, "Out of the total of 5-7 study disciplines allocated to the 2nd semester of the academic year 2019-2020, for how many of them did you use a video conferencing system?".

On average, the number of online courses (from a maximum of seven) for the investigated students was 3.45 (Q14), while the average number of courses that used an eLearning platform was only 1.78 (Q16); that represents $25 \%$ of the seven courses, so only one teacher out of four used virtual classes (1 and 2-blue and orange) (Figure 21).

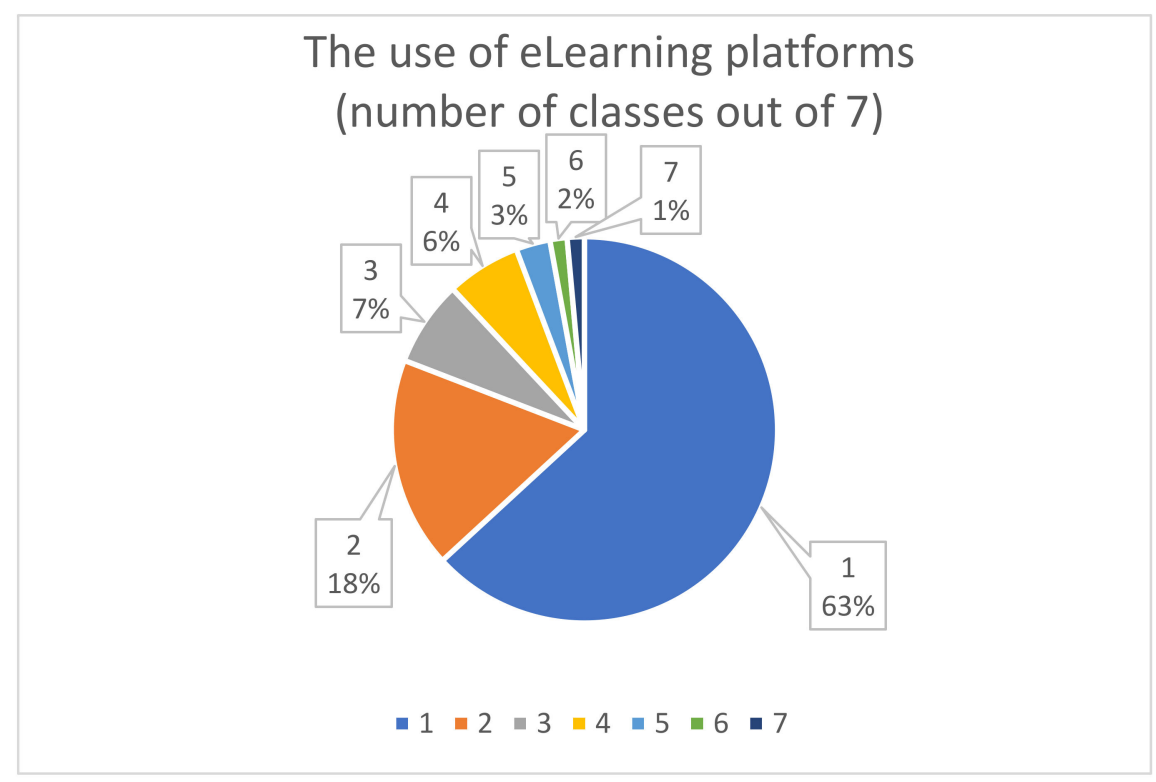

Figure 21. Q16, "Out of the total of 5-7 study subjects allocated to the 2nd semester of the academic year 2019-2020, for how many of them did you use an eLearning platform (Virtual Classroom)?".

3.2. Graphical Results for the Research Based on Official Information on the Situation from the Dean's Office

The results of the investigation conducted at the end of April were partially confirmed at the end of May by official information that showed that videoconferencing was used only at $16 \%$ and $48 \%$ levels in the exams for the Faculty of Science and the Faculty of Mining, respectively. At these two faculties of the University of Petroșani, the official information showed that email was used as an 
examination tool at 33\% and $40 \%$ levels in the exams for the Faculty of Science and the Faculty of Mining, respectively, and also that WhatsApp was used as an examination tool at $6 \%$ and $12 \%$ levels in the exams for the Faculty of Science and the Faculty of Mining, respectively. The online testing varied from $45 \%$ to $52 \%$ for the two faculties investigated (Table 3 and Figure 22).

Table 3. The type of exams conducted during the June 2020 session at the Faculty of Mining and the Faculty of Science of the University of Petroșani (source: Dean's Office).

\begin{tabular}{|c|c|c|c|c|}
\hline \multicolumn{1}{|c|}{ Faculty/Exam } & Faculty of Mining & $\mathbf{\%}$ & Faculty of Science & $\mathbf{\%}$ \\
\hline Exams conducted by email & $\mathbf{4 9}$ & $\mathbf{4 0} \%$ & $\mathbf{8 2}$ & $\mathbf{3 3} \%$ \\
\hline Exams conducted by WhatsApp & $\mathbf{1 5}$ & $\mathbf{1 2} \%$ & $\mathbf{1 5}$ & $\mathbf{6} \%$ \\
\hline Exams conducted by online testing & $\mathbf{6 4}$ & $\mathbf{5 2} \%$ & $\mathbf{1 1 2}$ & $\mathbf{4 5 \%}$ \\
\hline Classmarker & 30 & $\mathbf{2 4} \%$ & 2 & $\mathbf{1 \%}$ \\
\hline Testmoz & 10 & $\mathbf{8 \%}$ & 0 & $\mathbf{0} \%$ \\
\hline Google Forms & 14 & $\mathbf{1 1} \%$ & 106 & $\mathbf{4 3} \%$ \\
\hline Microsoft Forms & 10 & $\mathbf{8 \%}$ & 4 & $\mathbf{2 \%}$ \\
\hline Exams conducted by video conferencing & $\mathbf{5 9}$ & $\mathbf{4 8} \%$ & 39 & $\mathbf{1 6 \%}$ \\
\hline Zoom & 48 & $\mathbf{3 9} \%$ & 36 & $\mathbf{1 5 \%}$ \\
\hline Skype & 10 & $\mathbf{8} \%$ & 3 & $\mathbf{1 \%}$ \\
\hline Google Meet & 1 & $\mathbf{1 \%}$ & 0 & $\mathbf{0} \%$ \\
\hline Exams conducted by Virtual Classrooms & $\mathbf{2 3}$ & $\mathbf{1 9} \%$ & $\mathbf{6}$ & $\mathbf{2 \%}$ \\
\hline Google Clasroom & 9 & $\mathbf{7 \%}$ & 3 & $\mathbf{1 \%}$ \\
\hline Microsoft Teams & 4 & $\mathbf{3 \%}$ & 0 & $\mathbf{0} \%$ \\
\hline Microsoft OneNote Class & 10 & $\mathbf{8 \%}$ & 3 & $\mathbf{1 \%}$ \\
\hline Total number of exams & $\mathbf{1 2 3}$ & $\mathbf{1 0 0} \%$ & $\mathbf{2 4 8}$ & $\mathbf{1 0 0} \%$ \\
\hline
\end{tabular}

\section{Faculty/Type of exams conducted in June 2020}

Exams conducted bu Virtual Classrooms

Exams conducted by video conferencing

Exams conducted by online testing

Exams conducted by WhatsApp

Exams conducted by email

82

0

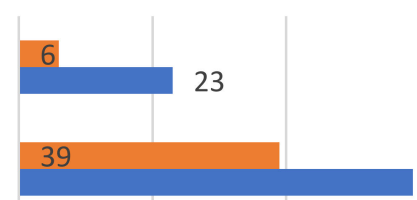

59

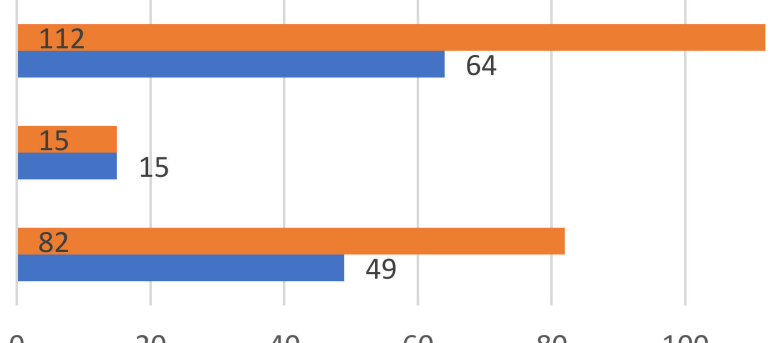

60

80

- Faculty of Sience $\quad$ Faculty of Mining

Figure 22. Summarized types of exams conducted during the June 2020 session at the Faculty of Mining and the Faculty of Science of the University of Petroșani (source: Dean's Office).

The authors have made an analogy between the data collected through the questionnaire and the data offered by the Dean's Office. It must be mentioned that data were not offered from the Faculty of Mechanical and Electrical Engineering (MEE) Dean's Office (Table 4). 
Table 4. The types of exams conducted during the June 2020 session at the Faculty of Mining and the Faculty of Science of the University of Petrosani (source: Dean's Office) compared with the responses offered by the 209 students at the end of April 2020.

\begin{tabular}{|c|c|c|c|c|}
\hline \multirow[b]{2}{*}{ Faculty/Exam } & \multicolumn{2}{|l|}{ Dean's Office } & \multicolumn{2}{|c|}{ Questionnaire } \\
\hline & $\begin{array}{l}\text { Faculty of Mine } \\
\text { and Faculty of Science from } \\
\text { the University of Petrosani }\end{array}$ & $\%$ & $\begin{array}{l}\text { University } \\
\text { of } \\
\text { Petrosani }\end{array}$ & $\%$ \\
\hline Exams conducted by email & 131 & $35 \%$ & 119 & $57 \%$ \\
\hline Exams conducted by WhatsApp & 30 & $8 \%$ & 48 & $23 \%$ \\
\hline Exams conducted by online testing & 176 & $47 \%$ & 109 & $52 \%$ \\
\hline Exams conducted by video conferencing & 98 & $26 \%$ & 78 & $37 \%$ \\
\hline Exams conducted by Virtual Classrooms & 29 & $8 \%$ & 62 & $30 \%$ \\
\hline Total number of exams/respondents & 371 & & 209 & \\
\hline
\end{tabular}

\subsection{Statistical Results}

In the statistical analysis performed by the authors, it was demonstrated that the survey conducted in April was validated by the teachers' options during May; even the university leadership would have opted for face-to-face testing or for the use of a Moodle eLearning platform. They carried out a multiple regression analysis in order to identify the effect that the implementation of online education at the University of Petroșani would have on the students. They analyzed the statistical connections using correlation analysis for the intensity of the connections between the variables and regression analysis to estimate the value of a dependent variable (effect), using the values of other independent variables (causes). The answers to "What was the number of hours per day dedicated to your online courses during the state of emergency?" (Q6) correlated with "What was the number of hours per day dedicated to conducting the courses in the classic format by you in the period prior to the declaration of the state of emergency?" (Q7) according to the following regression analysis (Table 5).

Table 5. Regression analysis of and correlation between the number of hours of online courses conducted per day and the number of hours of classic courses conducted per day.

\begin{tabular}{|c|c|c|c|c|c|c|}
\hline \multicolumn{7}{|c|}{ Model Summary } \\
\hline \multicolumn{2}{|r|}{ Model } & $\mathbf{R}$ & \multirow{2}{*}{$\begin{array}{c}\text { R Square } \\
0.085\end{array}$} & Adjusted R Square & \multicolumn{2}{|c|}{ Std. Error of the Estimate } \\
\hline \multicolumn{2}{|r|}{1} & $0.292^{\mathrm{a}}$ & & 0.081 & & \\
\hline \multicolumn{7}{|c|}{ ANOVA $^{b}$} \\
\hline & Model & Sum of Squares & df & Mean Square & $\mathbf{F}$ & Sig. \\
\hline \multirow{3}{*}{1} & Regression & 68.202 & 1 & 68.202 & 19.256 & $0.000^{c}$ \\
\hline & Residual & 733.176 & 207 & 3542 & & \\
\hline & Total & 801.378 & 208 & & & \\
\hline
\end{tabular}

a Predictors: (Constant), Hours of classic courses per day; ${ }^{\mathrm{b}}$ Dependent Variable: Hours of online courses per day; ${ }^{\mathrm{c}}$ Predictors: (Constant), Hours of classic courses per day.

The authors noticed that there was a very weak link (with a significance of correlation $\mathrm{R}=0.292<0.63$ for 209 degrees of freedom). The F-test also produces a high value (19.256), and the Sig. corresponding F statistic is $0.00(0.00)$, which indicates a significant linear relationship between two variables. Because both F is high and significance Sig. is low, it can be concluded that the results are not coincidental. The regression coefficient $R=0.292$ shows a weak link between the variable Hours of online courses per day, and the independent variable Hours of classic courses per day. The model explains $8.5 \%$ of the total variation of the variable $\left(R^{2}=0.085\right)$. The remaining $91.5 \%$ is due to other residual factors not included in the model. Thus, the transition to online learning is bad at the University of Petroșani

The answers to "Out of the total of 5-7 study disciplines allocated to the 2nd semester of the academic year 2019-2020, for how many of them did you use a video conferencing system?" (Q15) correlated with those to "Out of the total of 5-7 study disciplines allocated to the 2nd semester of 
the academic year 2019-2020, for how many of them did you use online courses?" (Q14), according to the following regression analysis (Table 6).

Table 6. Regression analysis of and correlation between the number of video conferencing courses conducted per day and the number of all online courses conducted per day.

\begin{tabular}{cccccc}
\hline \multicolumn{7}{c}{ Model Summary } \\
\hline \multicolumn{7}{c}{ Model } & R & R Square & Adjusted R Square & Std. Error of the Estimate \\
\hline 1 & $0.505^{\text {a }}$ & 0.255 & 0.252 & 1.2527 \\
\hline \multicolumn{7}{c}{ ANOVA } \\
\hline
\end{tabular}

The authors noticed that there was a weak link (with a significance of correlation $\mathrm{R}=0.505<0.63$ for 209 degrees of freedom). The F-test also produced a high value (70.927), and the Sig. corresponding F statistic is $0.00(0.00)$, which indicates a significant linear relationship between two variables. Because both F is high and the significance Sig. is low, it can be concluded that the results are not coincidental. The regression coefficient $R=0.505$ shows a weak link between the variable Hours of video conferencing courses per day, and the independent variable Hours of online courses per day. The model explains $25.5 \%$ of the total variation of the variable $\left(R^{2}=0.255\right)$. The remaining $74.5 \%$ is due to other residual factors not included in the model. Thus, the use of video conferencing as a method of eLearning is bad at the University of Petroșani.

Answers to "Out of the total of 5-7 study subjects allocated to the 2nd semester of the academic year 2019-2020, for how many of them did you use an eLearning platform (Virtual Classroom or Online Testing)?" (Q16) correlated with those to "Out of the total of 5-7 study disciplines allocated to the 2nd semester of the academic year 2019-2020, for how many of them did you use online courses?" (Q14), according to the following regression analysis (Table 7).

Table 7. Regression analysis of and correlation between the number of virtual classrooms used per day and the number of all online courses conducted per day.

\begin{tabular}{|c|c|c|c|c|c|c|}
\hline \multicolumn{7}{|c|}{ Model Summary } \\
\hline \multicolumn{2}{|r|}{ Model } & $\mathbf{R}$ & R Square & Adjusted R Square & \multicolumn{2}{|c|}{ Std. Error of the Estimate } \\
\hline \multirow{2}{*}{\multicolumn{2}{|c|}{1}} & $0.311^{\mathrm{a}}$ & 0.097 & 0.092 & \multicolumn{2}{|c|}{1.2637} \\
\hline & & \multicolumn{3}{|c|}{ ANOVA $^{b}$} & & \\
\hline \multicolumn{2}{|r|}{ Model } & Sum of Squares & df & Mean Square & F & Sig. \\
\hline \multirow{3}{*}{1} & Regression & 35.323 & 1 & 35.323 & 22.120 & $0.000^{c}$ \\
\hline & Residual & 330.552 & 207 & 1.597 & & \\
\hline & Total & 365.876 & 208 & & & \\
\hline
\end{tabular}

a Predictors: (Constant), Courses online out of total; ${ }^{\mathrm{b}}$ Dependent Variable: Virtual Classroom out of total; ${ }^{\mathrm{c}}$

Predictors: (Constant), Courses online out of total.

The authors noticed that there was a very weak link (with a significance of correlation $\mathrm{R}=0.311<0.63$ for 209 degrees of freedom). The F-test also produced a high value (22.120), and the Sig. corresponding F statistic is $0.00(0.00)$, which indicates a significant linear relationship between two variables. Because both $\mathrm{F}$ is high and the significance Sig. is low, it can be concluded that the results are not coincidental. The regression coefficient $R=0.311$ shows a weak link between the variable Virtual Classroom hours per day, and the independent variable Online Courses hours per day. The model explains $9.7 \%$ of the total variation of the variable $\left(R^{2}=0.097\right)$. The remaining $90.3 \%$ is 
influenced by other residual factors not included in the model. Thus, the use of the virtual classroom as a method of eLearning is very poor at the University of Petroșani.

The authors noticed that there was a strong link (with a significance of correlation $\mathrm{R}=0.909>0.63$ for 5 degrees of freedom - for email, WhatsApp, online tests, videoconferencing and virtual classroom). The F-test also produced a high value (14.272), and the Sig. corresponding F statistic is $0.032(0.00)$, which indicates a significant linear relationship between two variables. Because both $\mathrm{F}$ is high and the significance Sig. is low, it can be concluded that the results are not coincidental. The regression coefficient $\mathrm{R}=0.909$ shows a strong link between the dependent variable type of exam offered by the student survey proposed by us, and the independent variable type of exam set by the Dean's Office and proposed by the teachers. The model explains $82.6 \%$ of the total variation of the variable $\left(\mathrm{R}^{2}=0.826\right)$. The remaining $17.4 \%$ is due to other residual factors not included in the model. Thus, the testing methods proposed by us and validated by the students were confirmed by the teachers' options and invalidate the university leadership's options (Tables 8 and 9).

Table 8. Correlation between the type of exams set by the Dean's Office in May and the type of exam proposed by us and confirmed by the students in April.

\begin{tabular}{|c|c|c|c|}
\hline \multicolumn{4}{|c|}{ Correlations } \\
\hline & & Dean's Office & Questionnaire \\
\hline \multirow{3}{*}{ Dean's office } & Pearson Correlation & 1 & 0.909 * \\
\hline & Sig. (2-tailed) & & 0.032 \\
\hline & $\mathrm{N}$ & 5 & 5 \\
\hline \multirow{3}{*}{ Questionnaire } & Pearson Correlation & $0.909 *$ & 1 \\
\hline & Sig. (2-tailed) & 0.032 & \\
\hline & $\mathrm{N}$ & 5 & 5 \\
\hline
\end{tabular}

* Correlation is significant at the 0.05 level (2-tailed).

Table 9. Regression analysis of and correlation between the type of exams set by the Dean's Office in May and the type of exam proposed by us and confirmed by the students in April.

\begin{tabular}{|c|c|c|c|c|c|c|}
\hline \multicolumn{7}{|c|}{ Model Summary } \\
\hline \multicolumn{2}{|r|}{ Model } & \multirow{2}{*}{$\frac{\mathbf{R}}{0.909^{\mathrm{a}}}$} & \multirow{2}{*}{$\begin{array}{c}\text { R Square } \\
0.826\end{array}$} & Adjusted R Square & \multicolumn{2}{|c|}{ Std. Error of the Estimate } \\
\hline \multicolumn{2}{|r|}{1} & & & 0.768 & & \\
\hline \multicolumn{7}{|c|}{ ANOVA $^{b}$} \\
\hline & Model & Sum of Squares & df & Mean Square & F & Sig. \\
\hline \multirow{3}{*}{1} & Regression & 3026.604 & 1 & 3026.604 & 14.272 & $0.032^{c}$ \\
\hline & Residual & 636.196 & 3 & 212.065 & & \\
\hline & Total & 3662.800 & 4 & & & \\
\hline
\end{tabular}

a Predictors: (Constant), Dean's office; ${ }^{\mathrm{b}}$ Dependent Variable: Questionnaire; ${ }^{\mathrm{c}}$ Predictors: (Constant), Dean's office.

\section{Discussion}

eLearning has become a must during the COVID-19 Pandemic over the whole world and also in Romania. Romanian top universities transitioned to eLearning very easily, having a strong infrastructure. Primary, secondary and high schools, and also small universities have been confronted with the same challenge: to adapt the education system from a classical education system to an online education system based on eLearning. The focus of this study was set on these schools and small universities, which are similar from this point of view, because, prior to COVID-19, they used only classical education and almost never eLearning.

Additionally, based on the Romanian Higher Education structure, small universities are very important from a regional point of view, being able to reduce social disparities and also providing support for students that cannot afford an expensive education. These small universities are located in less developed regions and must support the development of these regions. This is why a small 
university, such as the University of Petrosani, is representative for this unusual period, such as these three pandemic months, months in which the whole Romanian education system has been virtual.

The need for this study became of major importance for the authors immediately after Romania declared, in 15 March 2020, the state of emergency. The authors have almost 10 years of experience in the field of eLearning and also in the field of management, and they realized the importance of this major change in the education system. The University of Petrosani, similarly to all the small universities and schools, is not entirely prepared for this change, from the online education point of view.

During the first month and a half of the state of emergency, the authors developed their own tools for online education based on the Microsoft 365 A1 license, and this work was presented in Chapter 2.3. Other teachers and school managers have tried to adapt to this situation, but it was very difficult in the context of a low level of training in the field of eLearning.

In the second period, during the end of April, the authors realized the lack of adaptation to this situation and tried to offer expertise to other teachers, and also began an investigation based on a questionnaire, having the support of a very important number of students, students that have been involved by the authors in online courses, online projects and web seminars. Using a large number of students in their investigation and receiving answers in a such short period of time was possible because, during 2016-2020, Eduard Edelhauser was the vice rector of the university for student affairs and, during February 2020, was the candidate for the Rector position at the University of Petrosani, being one of the most important figures for the students in the Petrosani academic community.

Then, following the third period of these three months, the end of May, when the authors had analyzed the data offered by the Dean's Office, unusual data based on the decision of each teacher, regarding the online examination tools proposed for the June 2020 exam session, were observed.

Based on the expertise of the authors, on the investigation based on a questionnaire among the students, and also on the processing of the data offered by the Dean's Office, they found some important results in this study:

$\checkmark$ Students adapt quickly to virtual education, and between March and May 2020, 87\% of them had participated in online courses;

$\checkmark$ Email was used as an examination tool at a $33-40 \%$ level;

$\checkmark$ WhatsApp was used as an examination tool at a $6 \%$ to $12 \%$ level;

$\checkmark$ The online testing varied from $45 \%$ to $52 \%$;

$\checkmark$ The most used equipment by the students was the smartphone, and $42 \%$ attended online courses on a smartphone;

$\checkmark$ Only $50 \%$ of the courses were actually conducted online;

$\checkmark$ Only $30 \%$ of the courses were conducted in video conferencing mode.

In the conclusion section, we extrapolate these results in the context of the Romanian education system.

\section{Conclusions}

The authors are concerned with the eLearning results during the years 2009-2013 for eLearning tools implemented at the University of Petroșani and also results in a few important papers. After more than seven years, the authors were forced to start another research project in the field of the implementation of eLearning due to the beginning of the COVID-19 pandemic, and they also analyzed the level of eLearning platform use in the Romanian education system. During these two months, Romania made spectacular steps, so at the end of April, most of the schools and universities had translated the classical education system into an online system. Thus, at the end of April, after they had previously implemented Microsoft eLearning tools in their teaching activity, the authors decided to start an investigation based on a questionnaire in their own university, and they found some important results. At the end of May, their investigation results were confirmed by an official statement from the Dean's 
Office. At two out of the three faculties of the University of Petroșani, the official information states that email was used as an examination tool at a 33-40\% level in the exams of the Faculty of Science and the Faculty of Mining; also, WhatsApp was used as an examination tool at a $6 \%$ to $12 \%$ level in the exams for the Faculty of Science and the Faculty of Mining. The online testing varied from $45 \%$ to $52 \%$ for the two faculties investigated. The results that were similar to those from their investigation demonstrate a low level of eLearning implementation at one of the smallest universities of Romania, because email and WhatsApp cannot be considered eLearning tools.

Additionally, they identified that University of Petroșani students have adapted quickly to virtual education, and between March and May 2020, 87\% of them participated in online courses; the students' most used equipment was the smartphone, and $42 \%$ of them attended online courses on a smartphone. Because a unitary eLearning platform was not implemented, the courses were mainly sent by email, because there were no digitized courses; the form of representation of a course was the PDF file, because there was no serious concern regarding the training of teachers-only $50 \%$ of the courses are actually conducted online, and because the conducting of video conferencing courses requires both equipment and skill, only $30 \%$ of the courses are conducted through video conferencing. The research also shows that the most popular video conferencing software at the University of Petroșani as in the whole of Romania is, by far, Zoom, and the most popular educational platforms used are those from Microsoft, Google and Facebook.

In the authors' opinion, in order to implement a real collaborative platform in a useful way and with complex functionalities at the University of Petroșani, the following steps must be followed. The university has to recruit and select at least two IT specialists whose only task is to manage the collaborative platform, virtual library and virtual classes. Additionally, it must offer training and must offer support by these specialists for each teacher for uploading courses, for creating the virtual classes, and for the design of the eContent and eTests. This must also include creating profiles for all students and training them with specialists. For the time being, we believe that only the following steps can be quickly taken: the management of a well-protected digital library and secure access, made by a specialized company, to this library (for example, SIVECO).

Because the authors had demonstrated that the University of Petrosani could be considered representative for the whole Romanian education system for eLearning implementation during the COVID-19 pandemic, the important conclusion of this short research is that the education in Romania will probably never look the same after the COVID-19 pandemic; classic education will probably suffer important changes due to these three months of exclusive online education in the whole system. Certainly, ICT will influence education more than it has done to date, future curricula will need to contain e-learning tools, classes will be increasingly virtual, and online testing will become commonplace.

Author Contributions: E.E. conducted the research based on questionnaires at the University of Petroșani and also designed his own virtual classes, presentations and tests. L.L.-D. established the theoretical background and performed the analyses of the Romanian eLearning system. All authors have read and agreed to the published version of the manuscript.

Funding: This research received no external funding.

Conflicts of Interest: The authors declare no conflict of interest.

\section{References}

1. Castle, S.R.; McGuire, C.J. An analysis of student self-assessment of online, blended, and face-to-face learning environments: Implications for sustainable education delivery. Int. Educ. Stud. 2010, 3, 36-40. [CrossRef]

2. Nie, D.; Panfilova, E.; Samusenkov, V.; Mikhaylov, A. E-Learning Financing Models in Russia for Sustainable Development. Sustainability 2020, 12, 4412. [CrossRef]

3. Kubiatko, M. Are ICT being used correctly? Small reflection about correct using of ICT in education. Probl. Educ. 21st Century 2017, 75, 4-5. 
4. National Council for the Financing of Higher Education-Report on The Number of Students in The Academic Year 2019-2020. Available online: http://www.cnfis.ro/wp-content/uploads/2020/04/SF_LMD-1oct2019_ preliminar_site.pdf (accessed on 23 June 2020).

5. Hastap Report About Global Self-Paced E-Learning Market 2020-2026. Available online: https://www.hashtap.com/@john.klok/global-self-paced-e-learning-market-2020-2026-business-plansmarket-size-industry-share-growth-manufacturers-and-outlook-with-fo-PxM4A1ZPLwbm (accessed on 23 June 2020).

6. National Institute of Statistics - Press Release 156 of June 25. 2019. Available online: https://insse.ro/cms/ sites/default/files/com_presa/com_pdf/sistemul_educational_2019_r.pdf (accessed on 23 June 2020).

7. Ellis, R.; Goodyear, P. Students' Experiences of e-Learning in Higher Education. In The Ecology of Sustainable Innovation; Routledge: New York, NY, USA, 2010; eBook Published 1 February 2013. [CrossRef]

8. Lee, J.; Song, H.D.; Hong, A.J. Exploring factors, and indicators for measuring students' sustainable engagement in eLearning. Sustainability 2019, 11, 985. [CrossRef]

9. Dabbagh, N.; Kitsantas, A. Supporting self-regulation in student-centered web-based learning environments. Int. J. E-Learn. 2004, 3, 40-47.

10. Leeds, E.; Campbell, S.; Baker, H.; Ali, R.; Brawley, D.; Crisp, J. The impact of student retention strategies: An empirical study. Int. J. Manag. Educ. 2013, 7, 22-43. [CrossRef]

11. Kim, T.D.; Yang, M.Y.; Bae, J.; Min, B.A.; Lee, I.; Kim, J. Escape from infinite freedom: Effects of constraining user freedom on the prevention of dropout in an online learning context. Comput. Hum. Behav. 2017, 66, 217-231. [CrossRef]

12. Vazquez-Cano, E. Mobile distance learning with smartphones and apps in higher education. Edu. Sci. Theory Pract. 2014, 14, 1505-1520. [CrossRef]

13. Zaranis, N.; Kalogiannakis, M.; Papadakis, S. Using mobile devices for teaching realistic mathematics in kindergarten education. Creat. Educ. 2013, 4, 1-10. [CrossRef]

14. Cochrane, T.; Bateman, R. Smartphones give you wings: Pedagogical affordances of mobile Web 2.0. Australas. J. Educ. Technol. 2010, 26, 1-14. [CrossRef]

15. Orozco-Messana, J.; Martínez-Rubio, J.M.; Gonzálvez-Pons, A.M. Sustainable Higher Education Development through Technology Enhanced Learning. Sustainability 2020, 12, 3600. [CrossRef]

16. Lee, D.; Watson, S.L.; Watson, W.R. The Relationships between Self-E_cacy, Task Value, and Self-Regulated Learning Strategies in Massive Open Online Courses. Int. Rev. Res. Open Distrib. Learn. 2020, 21, $23-39$.

17. Ranwala, D.; Alberg, A.J.; Brady, K.T.; Obeid, J.S.; Davis, R.; Halushka, P.V. Retreats to Stimulate Cross-Disciplinary Translational Research Collaborations: Medical University of South Carolina CTSA Pilot Project Program Initiative. In Strategies for Team Science Success; Hall, K., Vogel, A., Croyle, R., Eds.; Springer: Berlin, Germany, 2019.

18. Dima, L.L.; Edelhauser, E.; Ionică, A. eLearning Platforms in Romanian Higher Education. Annal. Univ. Petrosani Econ. 2010, 10, 137-148.

19. Edelhauser, E.; Ionică, A.; Lupu-Dima, L. Designing an Online Master Using an eLearning Platform at the University of Petroșani. In Proceedings of the 6th International Seminar Quality Management in Higher Education - QMHE 2010, Tulcea, Romania, 8-9 July 2010; pp. 435-438.

20. Juárez Santiago, B.; Olivares Ramírez, J.M.; Rodríguez-Reséndiz, J.; Dector, A.; García García, R.; González-Durán, J.E.E.; Ferriol Sánchez, F. Learning Management System-Based Evaluation to Determine Academic Efficiency Performance. Sustainability 2020, 12, 4256. [CrossRef]

21. Górska, D. E-learning in Higher Education. Person Chall. 2016, 6, 35-43. [CrossRef]

22. Vagarinho, P.J. Quality in e-learning: What should contain the definition? Revista EDaPECI, São Cristóvão (SE) 2020, 20, 103-118. [CrossRef]

23. Bestcolleges. Online Education Trends Report. 2020. Available online: https://res.cloudinary.com/ highereducation/image/upload/v1590520589/BestColleges.com/Education\%20Trends/BestColleges_ Student-Trends-Report-2020.pdf (accessed on 23 June 2020).

24. European Commission Education and Training Monitor. Publications Office of the European Union. 2019. Available online: https:/ec.europa.eu/education/sites/education/files/document-library-docs/volume-1-2019education-and-training-monitor.pdf (accessed on 23 June 2020).

25. Fischer, H.; Heise, L.; Heinz, M.; Moebius, K.; Koehler, T. How to identify e-learning trends in academic teaching. Interact. Technol. Smart Educ. 2015, 12, 31-43. [CrossRef] 
26. The Impact of the CORONAVIRUS on Global Higher Education. Available online: http://info.qs. com/rs/335-VIN-535/images/The-Impact-of-the-Coronavirus-on-Global-Higher-Education.pdf (accessed on 23 June 2020).

27. "Financial Newspaper" Article "How Spiru Haret Came to Have 300,000 Students Under the Eyes of The State Authorities". Available online: https:/www.zf.ro/politica/cum-a-ajuns-spiru-haret-sa-aiba-300000-de-studenti-sub-ochii-autoritatilor-statului-video-4667002 (accessed on 8 May 2020).

28. CourseMill - Online Educational Platform Access Interface. Available online: http://elearning.memory.ro: 8081/cm/cm710/home.html (accessed on 8 May 2020).

29. Edelhauser, E. Implementation of Microsoft Office 365 at the University of Petrosani, 3.500 Office 365 A1 License; Universitas Publishing House: Petroșani, Romania, 2013.

30. Istrate, O. Distance Education, Curricula Design; Agata Publishing House: Botoşani, Romania, 2000.

31. Online Educational Resources Access Platform. Available online: https://www.edu365.me/ro/scoala365 (accessed on 8 May 2020).

32. Online Educational Resources Access Platform. Available online: https://www.clasaviitorului.ro/ (accessed on 8 May 2020).

33. Educred-Portal for Teacher Support. Available online: https://digital.educred.ro/ (accessed on 8 May 2020).

34. Gheorghe Asachi Technical University of Iasi-Announcement About Online Courses. Available online: https://www.tuiasi.ro/noutati/studentii-profesorii-si-personalul-din-administratia-universitatii-tehniceau-la-dispozitie-doua-platforme-pentru-a-si-desfasura-activitatile-online/ (accessed on 22 May 2020).

35. Technical University of Cluj-Virtual Campus. Available online: https://constructii.utcluj.ro/anunturi/ campus-virtual-utcn-platforma-de-colaborare-si-comunicare-online.html (accessed on 22 May 2020).

36. Politehnica University Timisoara-Virtual Campus. Available online: https://elearning.upt.ro/ro/campusvirtual/ (accessed on 22 May 2020).

37. University POLITEHNICA of Bucharest-Course Portal. Available online: https://fiir.curs.pub.ro/2019/ (accessed on 22 May 2020).

38. University "Lucian Blaga" of Sibiu-Course Portal. Available online: https://classroom.ulbsibiu.ro/ro/ (accessed on 15 May 2020).

39. University of Oradea-Learning Centre. Available online: https://e.uoradea.ro/ (accessed on 15 May 2020).

40. University of Craiova—online Platforms. Available online: https://www.ucv.ro/it_fonduri_eur/servicii_web/ platforme_online.php (accessed on 15 May 2020).

41. Transilvania University of Brasov-e-Learning Platform. Available online: https://elearning.unitbv.ro/login/ index.php (accessed on 15 May 2020).

42. Edelhauser, E. The IT\&C Impact on the Romanian Industry and Over the Romanian Organizations Management, Habilitation for the Quality of Doctoral Supervisor in The Field of Doctoral Studies Engineering and Management. Cluj Napoca. 2014. Available online: https://www.utcluj.ro/media/documents/2014/08_ habilitation_thesis_Edelhauser_Eduard_2014.pdf (accessed on 8 May 2020).

43. Dobrițoiu, M.; Corbu, C.; Guță, A.; Urdea, G.; Bogdanffy, L. Computer Aided Training and Online Educational Platforms; Universitas Publishing House: Petroșani, Romania, 2019.

44. Edelhauser, E.; Leba, M.; Ionica, A.; Lupu-Dima, L.; Dragomirescu, E. eLearning Solutions for the Reconversion of the Workforce. In Proceedings of the 10th National Conference on Virtual Education, Virtual Learning-Virtual Reality, Brasov, Romania, 2-3 November 2012; pp. 262-268.

45. Microsoft 365 Platform. Available online: https://www.office.com/?ref=logout (accessed on 22 May 2020).

(C) 2020 by the authors. Licensee MDPI, Basel, Switzerland. This article is an open access article distributed under the terms and conditions of the Creative Commons Attribution (CC BY) license (http://creativecommons.org/licenses/by/4.0/). 